\title{
Trends in Research on Exosomes in Cancer Progression and Anticancer Therapy
}

\author{
Dona Sinha ${ }^{1, *}$, Sraddhya Roy ${ }^{1}$, Priyanka Saha ${ }^{1}$, Nabanita Chatterjee ${ }^{1}$ and Anupam Bishayee ${ }^{2, *}$ (i) \\ 1 Department of Receptor Biology and Tumour Metastasis, Chittaranjan National Cancer Institute, \\ Kolkata 700 026, India; sraddhya1@gmail.com (S.R.); poojasaha.saha79@gmail.com (P.S.); \\ nabanita.chatterje@yahoo.com (N.C.) \\ 2 Lake Erie College of Osteopathic Medicine, Bradenton, FL 34211, USA \\ * Correspondence: dona.sinha@cnci.org.in or donasinha2012@gmail.com (D.S.); abishayee@lecom.edu or \\ abishayee@gmail.com (A.B.)
}

Simple Summary: Intensive research in the field of cancer biology has discovered a unique mode of interplay between cells via extracellular bioactive vesicles called exosomes. Exosomes serve as intermediators among cells via their cargoes that, in turn, contribute in the progression of cancer. They are ubiquitously present in all body fluids as they are secreted from both normal and tumor cells. These minuscules exhibit multiple unique properties that facilitate their migration to distant locations and modulate the microenvironment for progression of cancer. This review summarizes the multifarious role of exosomes in various aspects of cancer research with its pros and cons. It discusses biogenesis of exosomes, their functional role in cancer metastasis, both protumorigenic and antitumorigenic, and also their applications in anticancer therapy.

Citation: Sinha, D.; Roy, S.; Saha, P.; Chatterjee, N.; Bishayee, A. Trends in Research on Exosomes in Cancer Progression and Anticancer Therapy. Cancers 2021, 13, 326.

https://doi.org/10.3390/

cancers13020326

Received: 23 November 2020

Accepted: 14 January 2021

Published: 17 January 2021

Publisher's Note: MDPI stays neutral with regard to jurisdictional clai$\mathrm{ms}$ in published maps and institutional affiliations.

Copyright: $\odot 2021$ by the authors. Licensee MDPI, Basel, Switzerland. This article is an open access article distributed under the terms and conditions of the Creative Commons Attribution (CC BY) license (https:// creativecommons.org/licenses/by/ $4.0 /)$.

\begin{abstract}
Exosomes, the endosome-derived bilayered extracellular nanovesicles with their contribution in many aspects of cancer biology, have become one of the prime foci of research. Exosomes derived from various cells carry cargoes similar to their originator cells and their mode of generation is different compared to other extracellular vesicles. This review has tried to cover all aspects of exosome biogenesis, including cargo, Rab-dependent and Rab-independent secretion of endosomes and exosomal internalization. The bioactive molecules of the tumor-derived exosomes, by virtue of their ubiquitous presence and small size, can migrate to distal parts and propagate oncogenic signaling and epigenetic regulation, modulate tumor microenvironment and facilitate immune escape, tumor progression and drug resistance responsible for cancer progression. Strategies improvised against tumor-derived exosomes include suppression of exosome uptake, modulation of exosomal cargo and removal of exosomes. Apart from the protumorigenic role, exosomal cargoes have been selectively manipulated for diagnosis, immune therapy, vaccine development, RNA therapy, stem cell therapy, drug delivery and reversal of chemoresistance against cancer. However, several challenges, including in-depth knowledge of exosome biogenesis and protein sorting, perfect and pure isolation of exosomes, large-scale production, better loading efficiency, and targeted delivery of exosomes, have to be confronted before the successful implementation of exosomes becomes possible for the diagnosis and therapy of cancer.
\end{abstract}

Keywords: tumor-derived exosomes; exosomal cargoes; protumorigenic effect; drug resistance; anticancer therapy

\section{Introduction}

Exosomes are bilayered endosomal nanovesicles, first discovered in 1983, as transferrin conjugated vesicles $(50 \mathrm{~nm})$ released by reticulocytes [1]. Due to the increasing interest of scientists in exosome biology, a consensus guideline was proposed by board members of International Society of Extracellular Vesicles under "minimal experimental requirements for definition of extracellular vesicles and their functions" (MISEV2014) which was 
later updated in 2018 (MISEV2018). The guidelines advocated norms for nomenclature, isolation, separation, characterization, functional studies, and reporting requirements for proper identification of and experimentation with extracellular vesicles and exosomes [2,3]. Exosomes are generally formed by inward budding of late endosomes, also known as multivesicular bodies (MVBs). Intraluminal vesicles (ILVs) of MVBs engulf a variety of biomolecules which are released into extracellular space as exosomes. Exosomes are anucleated particles naturally released by cells, surrounded by lipid bilayer and are not capable of replication. Exosomes are identified by size (30-200 nm) and surface markers, such as membrane-associated proteins, e.g., lysosome-associated membrane glycoprotein 3 (LAMP3)/CD63; intercellular adhesion molecule (ICAM1)/CD81; and tetraspanin membrane protein/CD9. Exosomes are observed in various body fluids, such as blood, plasma, saliva, urine, synovial fluid, amniotic fluid, and breast milk [4,5].

All cellular types (normal and diseased) secrete exosomes, mediating intercellular communications [6]. Exosomes exhibit heterogeneity in size-Exo-Large (90-120 nm), ExoSmall $(60-80 \mathrm{~nm})$, and the membrane-less exomere $(<50 \mathrm{~nm})$. Exosome-mediated intercellular transfer of specific repertoire of proteins, lipids, RNA and DNA confer physiological and /or pathological functions to the recipient targets. Exosomes regulate physiological functions, such as neuronal communication, immune responses, reproductive activity, cell proliferation homeostasis, maturation and cellular waste disposition. They also contribute in clinical disorders, including inflammation, cancer, cardiovascular diseases, neuronal pathologies and pathogenic infections [5].

Our review deals with exosomal contents, exosome-associated protumorigenic, antitumorigenic effect and therapeutics, unlike other reviews, which discuss combinational roles of all microvesicles in cancer progression $[7,8]$ or have primarily focused on tumor-derived exosomes (TEXs) with little information on therapeutics [9]. In contrast to reviews which have focused on specific exosomal cargoes and therapeutics [10,11], we have envisaged the exosomal contents, the mechanisms influencing cancer progression and their therapeutic implications in cancer management. The inexplicable nature of exosomes has raised concern about their role in the invasion and metastasis of cancer cells, encompassing epithelial-to-mesenchymal transition (EMT), angiogenesis, and immune regulation [12]. Thus, instead of reviewing the isolated impact of exosomes, e.g., evasion of immune surveillance [13] for cancer progression, we have tried to encompass exosome-mediated propagation of oncogenic signaling, epigenetic regulation, modulation of tumor microenvironment (TME) and immune escape, EMT, angiogenesis, metastasis and drug resistance. Considering the clinical applications, the exosomes serve as potent diagnostic and prognostic biomarkers because of their bioavailability, low toxicity and differentiated surface markers [5]. Recent reviews on exosomes have focused on therapeutic efficacy of exosomes by addressing extracellular vesicular interaction with the host immune system [14], constraints and opportunities available with bioengineering of exosomes [15-17], success against multiple cancers [18] and exosome-based drug delivery [19-21]. Anticancer treatments sometimes experience shortfall in their efficacy due to unwanted side effects of the therapeutic agents or shortened shelf-life, but exosomes serve as natural agents to overcome these issues and become a potent therapeutic agent [22]. However, instead of perceiving specific therapeutic potential of exosomes, the present review has tried to decipher the entire repertoire of exosomes, including both protumorigenic and antitumorigenic impact.

\section{Cargo Composition of Exosomes}

Exosomes are rich in enzymes, transcription factors, heat shock proteins (Hsps), major histocompatibility complex (MHC), cytoskeleton components, signal transducers, tetraspanins, lipids, RNAs and DNAs [6,23]. Detailed information about the exosomal components can be accessed via databases, such as ExoCarta [www.exocarta.org], EVpedia [http:/ / evpedia.info] and Vesiclepedia [www.microvesicles.org]. Though exosomes diverge in size and biomolecular inclusions, some common components are observed in all types [5]. Lipid components are cholesterol, sphingomyelin, glycosphingolipids, 
phosphatidylcholine, phosphatidylserines, phosphatidylethanolamines and saturated fatty acids [4]. RNAs include specific microRNAs (miRNAs), long non-coding RNAs (lncRNAs), vault RNA, Y-RNA, transfer RNAs (tRNAs), ribosomal RNA (rRNA) fragments (such as $28 \mathrm{~S}$ and $18 \mathrm{~S}$ rRNA subunits) and messenger RNAs (mRNAs) [24]. Exosomal cargo components also include mitochondrial DNA (mtDNA), single-stranded DNA, double-stranded DNA and retrotransposons [4,6]. Different protein forms include components of the immune system (MHC class I and II molecules, cytokines), endosomal sorting complexes required for the transport (ESCRT) complex, those involved in trafficking (tetraspanins, glycosylphosphatidylinositol-anchored proteins, Rabs, soluble N-ethylmaleimide-sensitive fusion protein attachment protein receptors (SNARES), flotillins, lipid-rafts residents [25] and those involved in carcinogenesis (oncoproteins, tumor suppressor proteins, and transcriptional factors) [4]. The plasma membrane (PM) proteins constitute the vesicle membrane for maintaining composition parity with the cell membrane which helps in sequestration of soluble ligands. Exosomal proteins are involved in (i) antigen presentation, (ii) cell adhesion, (iii) cell structure and motility, (iv) stress regulation, (v) transcription and protein synthesis, and (vi) trafficking and membrane fusion [26]. The structure of exosome with membrane proteins and cargoes have been depicted in Figure 1.

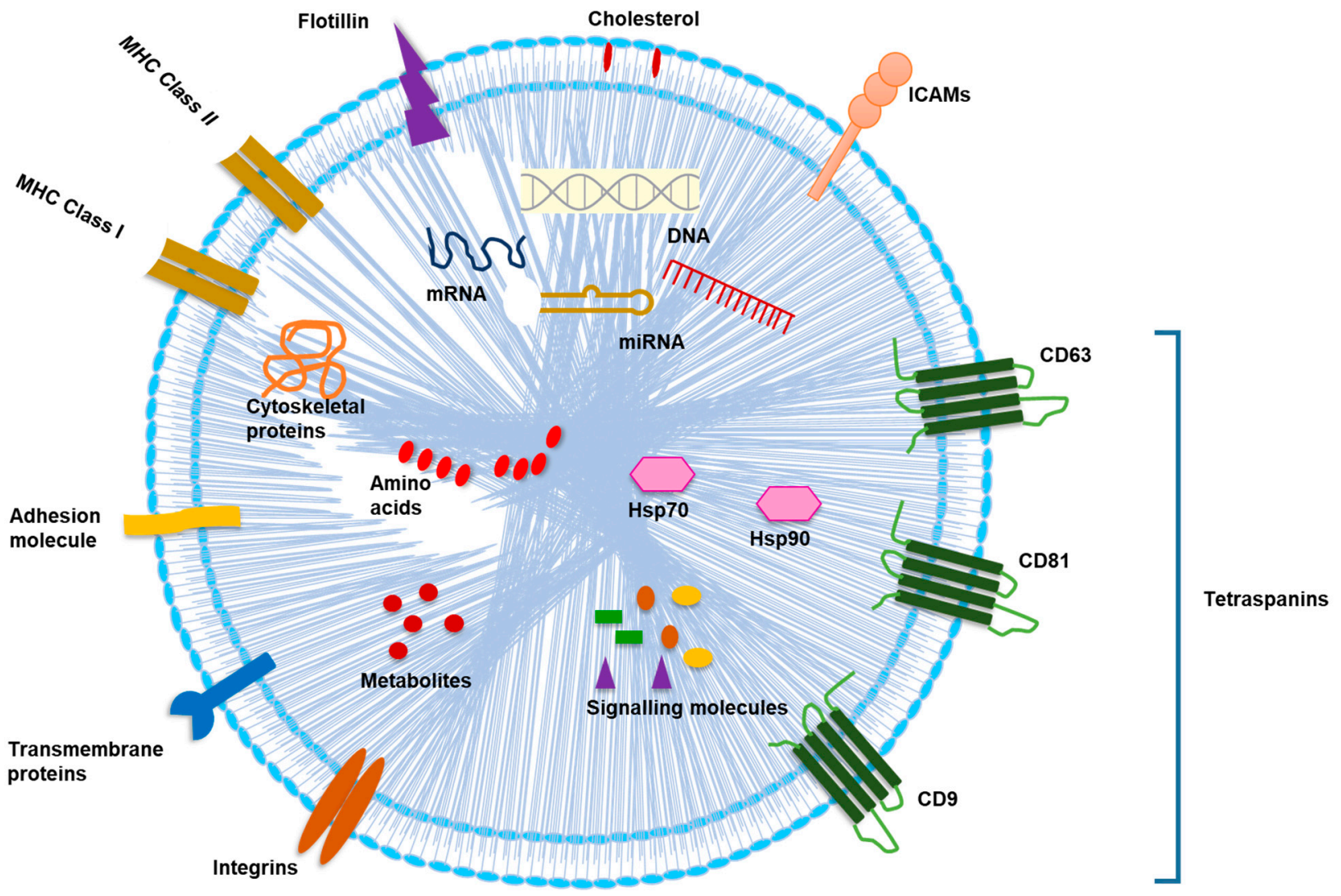

Figure 1. Structure of exosome with membrane proteins and cargoes. Exosomes consist of many constituents of a cell including DNA, RNAs, amino acids, proteins, metabolites, enzymes, lipids (cholesterol) and Hsps along with several cytosolic and cell-surface signaling proteins which are involved in intercellular communications. Exosomal membrane is rich in transmembrane proteins (tetraspanins such as CD81, CD63 and CD9), flotillin, ICAMs, integrins and adhesion molecules. They consist of immune components including MHC class I and class II molecules. Abbreviations: CD, cluster of differentiation; DNA, deoxyribonucleic acids; Hsps, heat shock proteins; ICAMs, intercellular adhesion molecules; MHC, major histocompatibility complex; mRNA, messenger RNA; miRNA, microRNA. 


\section{Exosome Biogenesis}

Endocytosis generates early endosomes via invagination of PM rich in lipid rafts. This internalizes the PM receptors which are either recycled or degraded. The exosome biogenesis involves a complex network of enzymatic actions and signal transductions. Early endosomes mature to MVBs or late endosomes upon internal budding of endosomes, forming ILVs [23]. MVB budding is primed with actin polymerization at PM lipid domains [27,28]. ADP ribosylation factor 6 (ARF6), along with phospholipase D2 (PLD2), converts ILVs into mature MVBs [29]. Heparanase enzyme stimulates the syndecan-syntenin-ALG-2 interacting protein X (ALIX) axis, upregulating exosome formation [30]. ARF6-induced actomyosin contractility and ESCRTs promote ILVs shedding from MVBs as exosomes [31]. The MVBs undergo one of the three type consequences [23,32] mentioned below:

(i) Recycling through the trans-Golgi network (TGN) which may be subdivided into a fast and a slow pathway, considering the duration taken by the specific proteins/lipids from internalization to re-exposure at the cell surface or exocytosis.

(ii) Lysosomal degradation by hydrolytic enzymes which are able to digest complex macromolecules.

(iii) Fusion of MVBs with the cell surface release exosomes via exocytosis. Additional materials may be incorporated to the TGN at any juncture and processed through the canonical secretory pathways.

\section{Sorting of Exosomal Cargoes}

\subsection{ESCRT-Dependent Sorting Pathway}

The ESCRT pathway participates in sorting ubiquitinated proteins of exosome, after being internalized within ILVs. The complex includes ESCRT-0, which identifies and processes ubiquitin-dependent cargo inside the vesicles; ESCRT-I and ESCRT-II evoke budding and ESCRT-III causes vesicle scission from endosomal membrane. Other accessory proteins such as ALIX aid in vesicle budding and vacuolar protein sorting associated protein 4 (VPS4) promotes scission [30,33].

\subsection{ESCRT-Independent Exosomal Sorting}

Ceramide and cholesterol, PLD2, or tetraspanins mediates ESCRT independent sorting machinery. Tetraspanins may promote incorporation of specific cargoes into exosome, e.g., CD9 facilitates encapsulation of metalloproteinase CD10 and CD63. Even the lipid composition and membrane dynamics of the early endosome and MVBs may regulate exosomal cargoes. Ceramide and neutral sphingomyelinase 2 (nSMase2) play a pivotal role in an ESCRT independent process of exosome formation, loading, and release [23]. Podoplanin, a transmembrane glycoprotein, is another regulator of exosome biogenesis and cargo sorting [31].

\section{Exocytosis and Secretion of Exosomes}

Exocytosis is exosomal secretion into the extracellular matrix (ECM) which is regulated by Rab GTPases, molecular motors, cytoskeletal proteins, SNAREs, intracellular $\mathrm{Ca}^{2+}$ levels (increased $\mathrm{Ca}^{2+}$ results in increased exosome secretion) and extracellular/intracellular $\mathrm{pH}$ gradients [23]. Vesicular SNAREs (v-SNARE) on the MVB bind with the target SNARE (t-SNARE), Syx 5, on the inner surface of the PM for mediating fusion of MVB with the cell membrane [34]. The fusion of exosome with PM occurs at the actin-rich zones of the invadopodia, promoting ECM degradation and metastasis, followed by their exocytosis into extracellular space [34]. Peptidyl arginine deiminases aid exosomal secretion by deaminating actin [35]. A negative feedback mechanism limits excess exosome secretion from the same cells [34].

\section{Rabs Control Endocytic Pathway}

The Rab GTPases belong to a large family of highly conserved proteins with 60 members, which regulate vesicular trafficking in eukaryotes. Different Rab forms are involved 
in endocytic trafficking-Rab4, 5, 9, 11a, 11b, 25 and 35 control recycling [36-39]; Rab5 and 7 cause endosomal maturation [40]; Rab 7 regulates sorting and degradation [41]; Rab 7, $27 \mathrm{a}$ and $\mathrm{b}$ control secretion of exosomes [42,43] and Rab5 overexpression causes release of exosomal markers [44]. Deregulation of the Rabs perturb the progression of cargo at specific endocytic locations. Rabs also play a crucial role in the regulation of tumor-derived exosomes. Rab11 influenced extrusion of exosome and interaction of MVB with autophagosomes [45] and promoted calcium dependent docking of MVBs to the PM [46] in K562 cells. Rab27A, in association with its GTPase activator, EP164, promoted exosome secretion by A549 lung cancer cells [47]. Rab27A/B are associated with exchange of exosomes between different cells of TME as well as with exosome secretion by macrophages [6]. Various types of Rabs involved in endocytic cargo trafficking have been depicted in Table 1.

Table 1. Different types of Rabs and their function in endocytic trafficking.

\begin{tabular}{|c|c|c|c|}
\hline Rabs & Effects & Functions & References \\
\hline Rab27 & \multirow{2}{*}{ Secretion of exosomes } & $\begin{array}{l}\text { Release of markers MHC II, CD63, and } \\
\text { CD81 in cancer cells }\end{array}$ & [32] \\
\hline Rab7, Rab27a/b & & Fusion with plasma membrane & [43] \\
\hline Rab5, Rab4, Rab35 & \multirow{3}{*}{ Recycling } & $\begin{array}{l}\text { Fast delivery of cargo to the plasma } \\
\text { membrane }\end{array}$ & [36] \\
\hline Rab5, Rab11a, Rab11b, Rab25 & & $\begin{array}{l}\text { Slow delivery of cargo to the } \\
\text { plasma membrane }\end{array}$ & {$[37,38]$} \\
\hline Rab9 & & Transportation to TGN & [39] \\
\hline Rab5, Rab7 & Endosome maturation & Release of Rab5 & [40] \\
\hline Rab7 & Sorting and degradation & $\begin{array}{l}\text { Reduction in } \mathrm{pH} \text { and acquisition of } \\
\text { hydrolytic enzymes }\end{array}$ & [41] \\
\hline $\begin{array}{l}\text { Rab5 overexpression }<\text { break } />\text { Note: } \\
\text { may be rescued by Rab7 }\end{array}$ & $\begin{array}{c}\text { Suppression of release of } \\
\text { exosomal markers syndecan, } \\
\text { CD63, and ALIX }\end{array}$ & $\begin{array}{l}\text { Inhibition of progression of endocytosed } \\
\text { material from early endosomes }\end{array}$ & {$[44]$} \\
\hline
\end{tabular}

Abbreviations: ALIX, ALG-2 interacting protein X; MHC-II, major histocompatibility complex II; TGN, trans-Golgi network.

\section{Exosomal Internalization by Recipient Cells}

Exosomes float in the ECM after their release and exosomal surface proteins help in detecting the target cells for their internalization [48]. Exosomes attach to specific target cells by receptor-ligand binding, mediated through integrins, tetraspanins and intercellular adhesion molecules, which then internalizes exosomes (Figure 2) by (i) clathrin/caveolinmediated endocytosis, (ii) uptake via lipid raft, (iii) macropinocytosis, (iv) direct fusion with the PM and (v) phagocytosis.

Clathrin protein forms a mesh like structure around the exosomes for its internalization. The PM of the recipient cells forms an inward invagination, followed by pinching off the clathrin coated vesicle from the membrane. The exosome empties all its contents in recipient cell's endosomes to perform specific functions [49]. Endocytosis, similar to the clathrin-dependent process, may be also mediated by caveolin-1 whose aggregations in PM form rafts. The invagination of the PM (caveolae) is rich in glycolipids, cholesterol and caveolin 1 [50]. Macropinocytosis involves distortion of PM forming protrusions from the membrane which encompass a region of extracellular fluid and exosomes, thereby internalizing exosomes. This process is Rac1-, actin- and cholesterol-dependent and it requires $\mathrm{Na}^{+} / \mathrm{H}^{+}$exchange [51]. LAMP-1, integrins or tetraspanins are involved in the fusion of exosomes with the PM of recipient cells [52,53]. Phagocytosis is similar to macropinocytosis where exosomes are internalized along with some extracellular fluids. This process is followed by both phagocytic cells_-like macrophages and dendritic cells (DCs) —and non-phagocytic cells like $\gamma \delta$ T cells [54]. During exosome uptake by soluble signaling, exosomal ligands are cleaved by cytoplasmic proteases and are bound to their respective 
receptors present on the PM of the recipient cells. In case of juxtacrine signaling, the ligands and receptors need to be in close proximity for efficient ligand-receptor binding [55]. Exosomal tetraspanins (CD9, CD63, CD81 and CD82) regulate cell fission and fusion, target cell selection [42], migration, adhesion, proliferation, and interaction between exosomes and recipient cells [56]. Size distribution in exosomes facilitates their internalization since cells have a propensity for loading smaller exosomes [5]. Oncogenic integrins play a dominant role during internalization of tumor-derived exosomes by recipient cells. Metastasis has been observed to be associated with exosome-integrins, such as $\alpha \mathrm{v} \beta 6$ integrin in prostate, $\alpha v \beta 5$ integrins in liver and $\alpha 6 \beta 4$ and $\alpha 6 \beta 1$ integrins in lung [56].

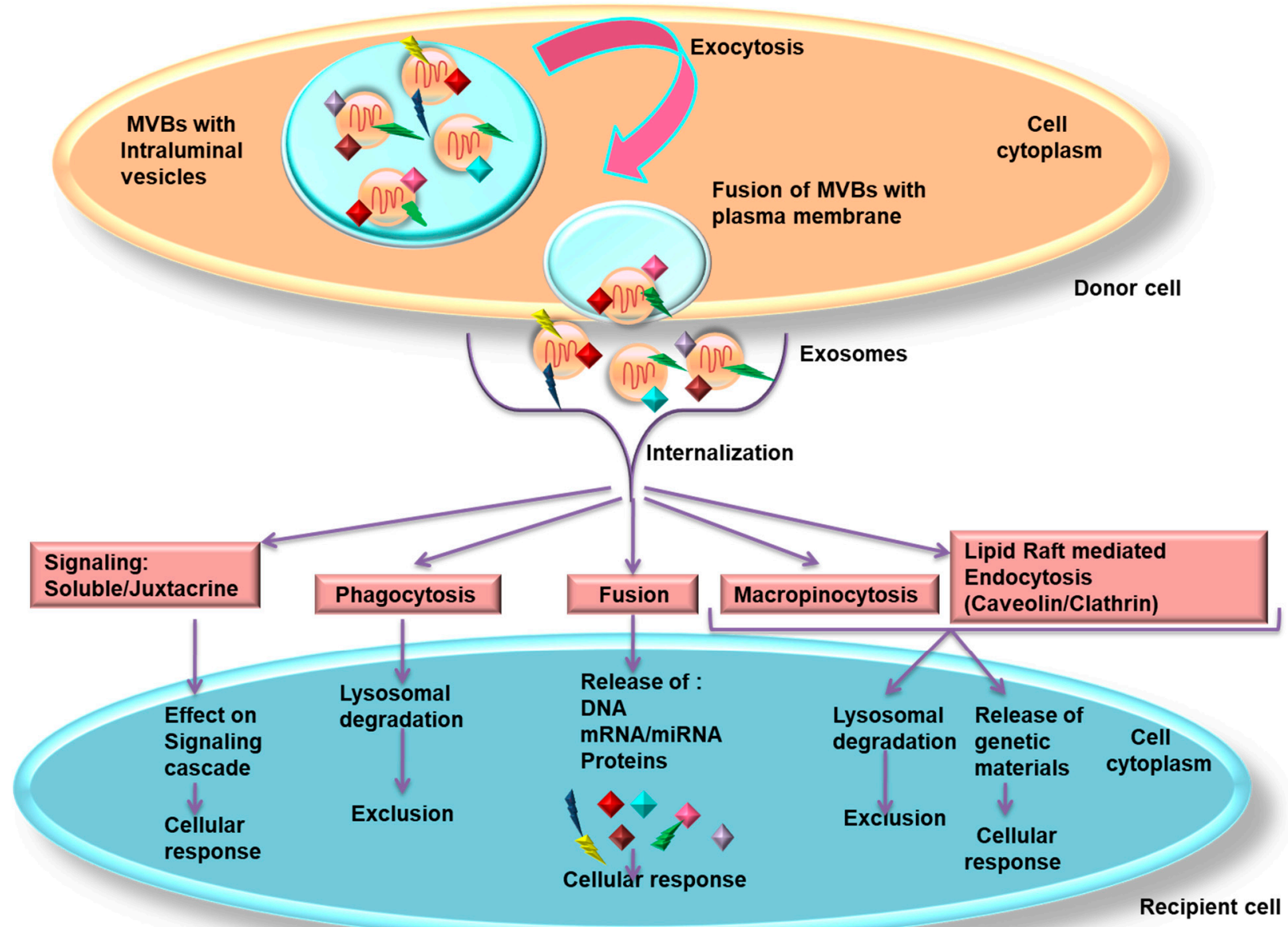

Figure 2. Mechanisms of internalization of exosomes. The exosomes inside the MVBs are extruded out from the donor cells by exocytosis on merging with plasma membrane. The released exosomes are then internalized via different modes: soluble/juxtacrine signaling; phagocytosis; fusion; micropinocytosis and lipid raft mediated endocytosis. The lipid raft mediated endocytosis can be either clathrin or caveolin protein dependent. Exosomes internalized by soluble/juxtacrine signaling affect the signaling cascade of the recipient cell. During phagocytosis, the exosomes undergo degradation, whereas, in the fusion event, genetic material is released that causes cellular response. In macropinocytosis and lipid raft-mediated endocytosis, the exosomes either undergo lysosomal degradation or mediate cellular response. Abbreviations: mRNA, messenger RNA; miRNA, microRNA; MVBs, multivesicular bodies.

\section{TEX}

The TEXs influence shaping of the TME, tumor progression, invasion and premetastatic niche formation, metastasis, angiogenic switch, and immune escape by paracrine subversion of local and distant microenvironments [57]. 


\subsection{Oncogenic Signaling Involved in Exosomal Trafficking}

According to the genometastatic theory, complex biomolecules in exosomes transfer oncogenic traits to target cells. Matrix cells in the TME interact with their oncogenic counterparts through exosomes and mediate tumor evolution and progression. Exosomal cargoes confer oncogenic transformation, EMT, immune surveillance evasion, invasion, and metastatic properties to the recipient cells [58]. Hypoxia and extracellular acidity culminate in greater release of TEXs [58]. Cells having even one oncosuppressor mutation are more prone towards uptake of exosomal oncogenic factors. Mutations leading to upregulated mitogen-activated protein kinase (MAPK) signaling in cancer cells elevated exosomes release [59]. Secretion of exosomes by activated platelets promoted MAPK and phosphoinositide 3-kinase (PI3K) / protein kinase B (Akt)/matrix metalloproteinase (MMP) signaling during cancer progression [31]. Expression of oncogenic RAS in non-tumorigenic epithelial cells promoted secretion of oncoprotein-rich exosomes [60]. Robust expression of oncogenic and truncated forms of epidermal growth factor receptor (EGFR) vIII in glioma cells augmented exosomal secretion and transfer of oncogenic activity to other normal cells [61]. Mutation of liver kinase B1 (STK11), a tumor suppressor, increased exosome secretion in lung cancer [62]. Secretion of exosomal mtDNA induced anaerobic metabolism and dormancy in cancer cells [31].

\subsection{Exosomal miRNA-Mediated Cancer Promotion}

Breast TEXs, enriched with Dicer, Protein Argonaut 2, and transactivation response element RNA-binding protein, processed precursor miRNAs into mature miRNAs for gene silencing in target cells and induced non-tumorigenic epithelial cells to form tumors [63]. Exosomal miRNAs suppressed cell proliferation by downregulating the C-XC motif chemokine ligand 12 (CXCL12); exosomal-miR-23b augmented cell quiescence by inhibiting myristoylated alanine-rich $\mathrm{C}$-kinase substrate expression in the metastatic niche [64]; miR-10b molded the TME to promote tumor metastasis [65] of breast cancer (BC) cells. Astrocyte-derived exosomes suppressed phosphatase and tensin homolog (PTEN) by intracellular trafficking of miR-19a in metastatic BC and melanoma brain metastasis models [66]. Release of exosomal miR-1245 from mutant p53 cancer cells reoriented macrophages to transforming growth factor- $\beta$ (TGF- $\beta$ )-rich tumor-associated macrophages (TAMs) which, in turn, propagated tumor progression [67]. Exosomal miR-105 and miR-939 in BC and miR-181c in brain cancer dissolved tight junctions, caused vascular leakiness and induced metastasis [31].

\subsection{Exosomes and TME}

TEXs are well documented for immune suppression by multiple interactions with immune cells of the TME (Figure 3). They hinder helper and cytotoxic T-cell activation and function, activate regulatory T-cell (Tregs), inhibit cytotoxicity of natural killer (NK) cells, augment differentiation of myeloid-derived suppressor cells (MDSCs) and reduce leukocyte adhesion [34]. Exosomes modulate the TME by extracellular signal-regulated kinase (ERK)-mediated cell growth or apoptosis. Interaction of stromal cells and tumor via exosomes inflict dissemination of tight junctions, generating a suitable niche for metastasis [68]. TEXs induced cancer-associated fibroblasts (CAFs) for exosomes' release [69]. The transfer of CAF-derived exosomal cargoes in the form of metabolic intermediates of the tricarboxylic acid cycle to cancer cells promotes neoplastic growth by alteration of glycolysis and glutamine-dependent reductive carboxylation [70]. Exosomes transformed fibroblasts into CAFs in melanoma [71]. CAFs or mesenchymal stem cells (MSCs) derived exosomes maneuvered Wnt signaling-induced migration [68]. Exosomes expressing Fas ligand activated CD8+ T-cell apoptosis [72]. Exosomal $\alpha \mathrm{v} \beta 6$ integrin inhibited the signal transducer and activator of transcription 1 (STAT1)/MX1/2 signaling in cancer cells and reprogramed monocytes into the M2 phenotype [73]. Exosomal miR-146a-5p from hepatocellular carcinoma (HCC) cells induced M2 polarization [74]. BC cell derived exosomes inhibited NK cells [75] and infiltrated neutrophils into tumors [76]. Melanoma-derived 
exosomes perturbed maturation of DCs in lymph nodes [77]. However, TEXs can supply antigens to DCs for cross-presentation to cytotoxic T cells [78]. Administration of topotecan/radiation induced the release of exosomal immunostimulatory DNA, which inflicted DC maturation and cytotoxic T cell activation [31]. Programmed death ligand 1 (PD-L1)-positive exosomes positively correlated with head and neck squamous cancer cells (HNSCC) progression in patients and administration of anti-PD-L-1 antibodies inhibited the immunosuppressive function of PD-L1 [79].

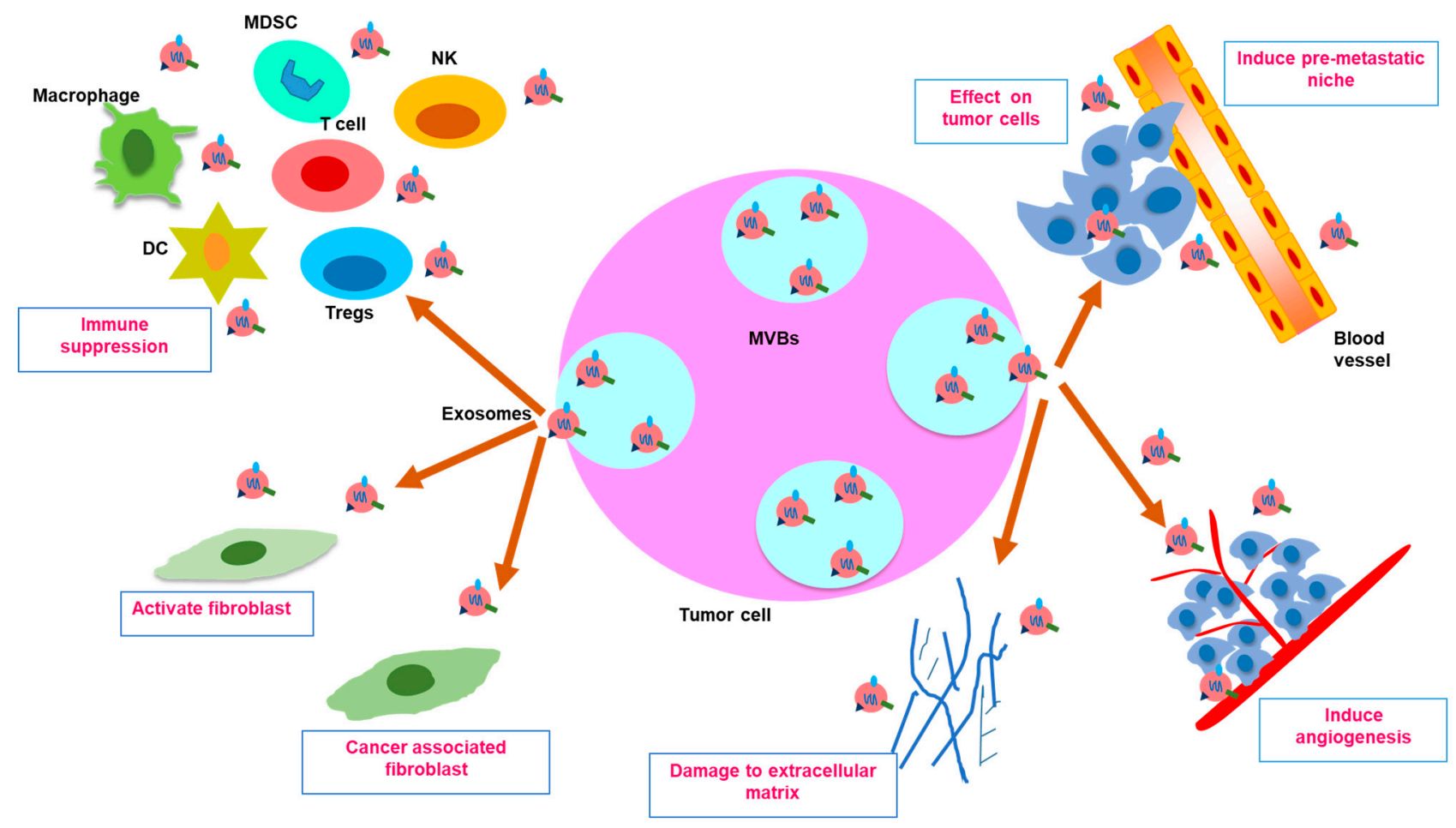

Figure 3. Exosomes in tumor microenvironment. Exosomes secreted from tumor cells containing MVBs exhibited a dynamic signaling between tumor cells and the TME. Exosomes may lead to immune suppression by downregulating macrophages, DC, T cells and NK cells and upregulating immunosuppressive cells like Tregs, MDSCs and TAMs. Exosomes induced differentiation of fibroblasts, activation of CAFs and degradation of ECM, which are associated with TME construction. They are involved in the alteration of ECM, hypoxia-mediated angiogenesis and the formation of pre-metastatic niches that trigger the metastatic escape of tumor cells. Abbreviations: CAFs, cancer-associated fibroblasts; ECM, extracellular matrix; DCs, dendritic cells; MDSCs, myeloid-derived suppressor cells; NK cells, natural killer cells; TAMs, tumor-associated macrophages; TME, tumor microenvironment; Tregs, tumor regulatory cells.

\subsection{Impact of Exosomes on EMT, Invasion, Metastasis and Angiogenesis}

Exosomal cargoes CD151 and Tspan8 are related with ECM degradation, stromal reprogramming, cell motility and tumor progression [80]. EMT was induced by exosomal miR-663b in bladder cancer [81]; lncRNA SOX2 overlapping transcript (Sox2ot) in pancreatic ductal adenocarcinoma (PDAC cells) [82]; and TGF- $\beta$-enriched TEXs in myofibroblasts [83]. Migration of tumor cells was facilitated by the exosome-mediated transfer of $\alpha \mathrm{v} \beta 6$ in prostate cancer [84]; miR-21 in bladder cancer [85]; TAM derived exosomes in gastric cancer (GC) cells [86]; and lncRNA ubiquitin-fold modifier conjugating enzyme 1 (UFC1) in non-small cell lung carcinoma (NSCLC) [87]. Exosomal lncRNA zinc finger antisense 1 (ZFAS1) induced EMT and migration in GC cells [88]. Metastasis was promoted by exosomal EGFR in GC [89]; MMP1 mRNA in ovarian cancer [90]; miR-25-3p, miR-130b-3p, $\mathrm{miR}-425-5 \mathrm{p}$ in colorectal cancer cells (CRC) [91]; miR-106b in lung cancer [92]; and miR-21 in oesophageal cancer [93]. Cell proliferation and invasion was induced by exosomal miR-1260b in lung adenocarcinoma [94] and miR-222 in PDAC [95]. Angiogenesis and 
tumor progression were influenced by exosome mediated Wnt $4 / \beta$-catenin signaling in CRC [96] and by vascular endothelial growth factor A (VEGF-A) enriched exosomes in brain endothelial cells [97]. Tumor progression was augmented by exosomal miRNAs from TP53-mutant cells in colon cancer cells [98] and by exosomal lncRNA ZFAS1 in GC [92]. Exosomal miR-21 reduced apoptosis in GC cells [99], exosomal IL-6 induced metastasis in BC cells [100], exosomal HSP70 induced tumor progression in MSC cells [101], and exosomal TGF- $\beta$ promoted tumor growth in LAMA84 cells [102]. Various recent studies based on the tumor promoting effect of exosomes have been listed in Table 2 .

Table 2. Tumor-promoting effects of exosomal cargoes on recipient cells.

\begin{tabular}{|c|c|c|c|c|c|}
\hline Exosome Donor Cells & Exosomal Cargo & Target Cells & Effects & Mechanisms & References \\
\hline \multirow{2}{*}{ Human prostate cancer (PC3) cells } & \multirow{2}{*}{ Integrin $\alpha_{V} \beta_{6}$} & $\begin{array}{l}\text { Peripheral blood } \\
\text { mononuclear cells } \\
\text { and THP-1 } \\
\text { monocyte cells }\end{array}$ & $\uparrow \mathrm{M} 2$ polarization & $\begin{array}{l}\downarrow \text { STAT1 } / \mathrm{MX} 1 / 2 \\
\text { signaling }\end{array}$ & {$[73]$} \\
\hline & & $\begin{array}{l}\text { Human prostate } \\
\text { cancer DU145 cells }\end{array}$ & $\begin{array}{l}\uparrow \text { Cell adhesion and } \\
\text { migration }\end{array}$ & $\begin{array}{l}\uparrow \text { Latency-associated } \\
\text { peptide-TGF- } \beta\end{array}$ & {$[84]$} \\
\hline $\begin{array}{l}\text { HCC (mouse Hepa1-6, H22, and } \\
\text { human HepG2, H7402) cells }\end{array}$ & $\operatorname{miR}-146 a-5 p$ & $\begin{array}{l}\text { Mouse RAW264.7 } \\
\text { cells, THP-1 cells, } \\
\text { mice peritoneal } \\
\text { macrophages }\end{array}$ & $\begin{array}{l}\uparrow \text { Pro-inflammatory } \\
\text { factors, } \uparrow \mathrm{M} 2 \\
\text { polarization, } \uparrow \mathrm{T} \text {-cell } \\
\text { exhaustion by M2 } \\
\text { macrophages }\end{array}$ & $\begin{array}{c}\uparrow N F-\kappa \mathrm{B}, \uparrow \mathrm{p}-\mathrm{STAT} 3 \\
\downarrow \mathrm{p}-\mathrm{STAT} 1\end{array}$ & {$[74]$} \\
\hline $\begin{array}{l}\text { Human Bladder cancer (T24 and } \\
\text { 5637) cells }\end{array}$ & $\operatorname{miR}-663 b$ & T24 and 5637 cells & $\begin{array}{l}\uparrow \text { Cell proliferation, } \\
\uparrow E M T\end{array}$ & $\begin{array}{l}\downarrow \text { ERF, } \downarrow \text { E-cadherin, } \\
\uparrow \text { Vimentin }\end{array}$ & {$[81]$} \\
\hline $\begin{array}{l}\text { Human PDAC (Hs } 766 \mathrm{~T} \text { ) and } \\
\text { metastatic (Hs 766T-L2) cells }\end{array}$ & lncRNA-Sox2ot & $\begin{array}{l}\text { Human PDAC } \\
(\mathrm{BxPC}-3) \text { cells }\end{array}$ & $\begin{array}{c}\uparrow \mathrm{EMT}, \uparrow \text { stemness, } \\
\uparrow \text { invasion and } \\
\text { metastasis }\end{array}$ & $\uparrow$ Sox-2 & {$[82]$} \\
\hline Human bladder cancer (T24) cells & $\operatorname{miR}-21$ & $\begin{array}{l}\text { Human THP-1 } \\
\text { cell-derived } \\
\text { macrophages }\end{array}$ & $\begin{array}{c}\uparrow \mathrm{M} 2 \text { polarization, } \\
\uparrow \text { tumor cell } \\
\text { migration and } \\
\text { invasion }\end{array}$ & $\begin{array}{c}\downarrow \text { PTEN, } \\
\uparrow \mathrm{PI} 3 \mathrm{~K} / \text { Akt-STAT3 } \\
\text { signaling }\end{array}$ & {$[85]$} \\
\hline $\begin{array}{c}\text { M2 polarized } \\
\text { macrophages (TAMs) }\end{array}$ & Apolipoprotein E & $\begin{array}{c}\text { Mouse gastric } \\
\text { carcinoma (MFC) } \\
\text { cells }\end{array}$ & $\uparrow$ Cell migration & 个PI3K-Akt signaling & {$[86]$} \\
\hline $\begin{array}{c}\text { Human NSCLC (A549 and } \\
\text { H1299) cells }\end{array}$ & lncRNA UFC1 & A549 and H1299 cells & $\begin{array}{c}\uparrow \text { Cell proliferation, } \\
\uparrow \text { migration, } \\
\uparrow \text { invasion }\end{array}$ & $\begin{array}{c}\downarrow \text { PTEN via } \\
\text { EZH2-mediated } \\
\text { epigenetic silencing }\end{array}$ & {$[87]$} \\
\hline Human GC (BGC-823) cells & lncRNA-ZFAS1 & $\begin{array}{c}\text { Human GC } \\
\text { (MKN-28) cells }\end{array}$ & $\begin{array}{l}\uparrow \mathrm{EMT}, \uparrow \text { cell } \\
\text { proliferation, } \\
\uparrow \text { migration }\end{array}$ & $\begin{array}{c}\uparrow \text { Cyclin D1, } \uparrow \text { Bcl-2, } \\
\downarrow \text { Bax, } \downarrow \text { E-cad, } \uparrow N \text {-cad, } \\
\uparrow \text { Slug }\end{array}$ & {$[88]$} \\
\hline Human GC (SGC7901) cells & EGFR & $\begin{array}{l}\text { Primary mouse liver } \\
\text { cells }\end{array}$ & $\begin{array}{l}\uparrow \text { Cell proliferation, } \\
\uparrow \text { metastasis }\end{array}$ & $\begin{array}{c}\downarrow \mathrm{miR}-26 \mathrm{a} / \mathrm{b}, \uparrow \mathrm{HGF}, \\
\uparrow \mathrm{c}-\mathrm{Met}\end{array}$ & [89] \\
\hline Human CRC (HCT116) cells & $\begin{array}{l}\text { miR-25-3p, } \\
\text { miR-130b-3p and } \\
\text { miR-425-5p }\end{array}$ & $\begin{array}{l}\text { Macrophages } \\
\text { RAW264.7 }\end{array}$ & $\begin{array}{c}\uparrow \mathrm{M} 2 \text { polarization, } \\
\uparrow \mathrm{EMT}, \uparrow \text { liver } \\
\text { metastasis }\end{array}$ & $\begin{array}{c}\uparrow \text { CXCL12/CXCR4 } \\
\text { axis, } \downarrow \text { PTEN, } \\
\uparrow \text { PI3K-Akt signaling }\end{array}$ & {$[91]$} \\
\hline $\begin{array}{l}\text { Human lung cancer (SPC-A-1 and } \\
\text { H1299) cells }\end{array}$ & $\operatorname{miR}-106 b$ & $\begin{array}{l}\text { SPC-A-1 and H1229 } \\
\text { cells }\end{array}$ & $\begin{array}{l}\uparrow \text { Migration and } \\
\text { invasion }\end{array}$ & $\downarrow$ PTEN & {$[92]$} \\
\hline $\begin{array}{l}\text { Human esophageal cancer } \\
\text { (EC9706) cells }\end{array}$ & $\operatorname{miR}-21$ & EC9706 cells & $\uparrow$ Metastasis & $\begin{array}{c}\downarrow \mathrm{PDCD} 4, \uparrow \mathrm{MMP} 2, \\
\uparrow \mathrm{MMP9}\end{array}$ & [93] \\
\hline $\begin{array}{l}\text { Human lung adenocarcinoma } \\
\text { (H1299) cells }\end{array}$ & miR-1260b & Human A549 cells & $\begin{array}{c}\uparrow \text { Cell invasion, } \uparrow \text { cell } \\
\text { proliferation, } \uparrow \text { drug } \\
\text { resistance }\end{array}$ & $\begin{array}{c}\uparrow W n t / \beta \text {-catenin } \\
\text { signaling, } \downarrow \text { sFRP1, } \\
\downarrow \text { Smad4 }\end{array}$ & [94] \\
\hline $\begin{array}{c}\text { Human PDAC (Capan-1 and Hs } \\
\text { 766T-L3) cells }\end{array}$ & miR-222 & $\begin{array}{l}\text { PDAC (Capan-1 and } \\
\text { Hs 766T-L3 cells) }\end{array}$ & $\begin{array}{l}\uparrow \text { Cell invasion, } \\
\uparrow \text { metastasis }\end{array}$ & $\begin{array}{c}\uparrow A k t, \downarrow P P P 2 R 2 A, \\
\uparrow p-P 27\end{array}$ & [95] \\
\hline
\end{tabular}


Table 2. Cont.

\begin{tabular}{|c|c|c|c|c|c|}
\hline Exosome Donor Cells & Exosomal Cargo & Target Cells & Effects & Mechanisms & References \\
\hline $\begin{array}{c}\text { Hypoxic human CRC (HT29 and } \\
\text { HCT116) cells }\end{array}$ & Wnt4 & $\begin{array}{l}\text { Endothelial } \\
\text { (HUVECs) and CRC } \\
\text { (HT29) cells }\end{array}$ & $\begin{array}{l}\uparrow \text { Proliferation, } \\
\text { angiogenesis, } \\
\uparrow \text { migration }\end{array}$ & $\uparrow \beta$-Catenin signaling & [96] \\
\hline $\begin{array}{l}\text { TP53-mutant (HT29) colon } \\
\text { cancer cells }\end{array}$ & $\begin{array}{l}\text { miR-1249-5p, } \\
\text { miR-6737-5p, and } \\
\text { miR-6819-5p }\end{array}$ & $\begin{array}{l}\text { Human colon } \\
\text { fibroblasts } \\
\text { (CCD-18Co) cells }\end{array}$ & $\uparrow$ Tumor progression & $\downarrow$ TP53 & {$[98]$} \\
\hline $\begin{array}{l}\text { Murine bone marrow-derived } \\
\text { macrophages }\end{array}$ & miR-21 & $\begin{array}{l}\text { Human GC (MFC, } \\
\text { MGC-803) cells }\end{array}$ & $\begin{array}{l}\downarrow \text { Apoptosis, } \\
\uparrow \text { resistance to } \\
\text { cisplatin }\end{array}$ & $\begin{array}{c}\uparrow \mathrm{PI} 3 \mathrm{~K} / \mathrm{AKT} \\
\text { signalling, } \downarrow \text { PTEN }\end{array}$ & [99] \\
\hline $\begin{array}{l}\text { Co-culture of THP-1-derived } \\
\text { macrophages exposed to } \\
\text { apoptotic human BC (MCF-7 or } \\
\text { MDA-MB-231) cells }\end{array}$ & IL-6 & $\begin{array}{l}\text { Naive (MCF-7 or } \\
\text { MDA-MB-231) cells }\end{array}$ & $\begin{array}{l}\uparrow \text { Proliferation, } \\
\uparrow \text { metastasis }\end{array}$ & $\begin{array}{c}\uparrow \mathrm{p}-\mathrm{STAT} 3, \uparrow \mathrm{cyclin} \\
\mathrm{D} 1, \uparrow \mathrm{MMP} 2, \uparrow \mathrm{MMP9}\end{array}$ & [100] \\
\hline Human lung cancer (A549) cells & HSP70 & $\begin{array}{l}\text { MSCs extracted from } \\
\text { human adipose tissue }\end{array}$ & $\begin{array}{l}\text { Pro-inflammatory } \\
\text { MSCs, } \uparrow \text { tumor } \\
\text { growth }\end{array}$ & $\begin{array}{l}\uparrow \mathrm{TLR}-2 / \mathrm{NF}-\mathrm{kB} \\
\text { signaling, } \uparrow \mathrm{IL}-6 \text {, } \\
\uparrow \mathrm{IL}-8, \uparrow \mathrm{MCP}-1\end{array}$ & {$[101]$} \\
\hline $\begin{array}{l}\text { Human chronic myeloid leukemia } \\
\text { (LAMA84) cells }\end{array}$ & TGF- $\beta$ & LAMA84 cells & 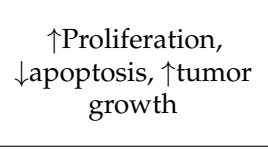 & $\begin{array}{c}\uparrow \text { SMAD } 2 / 3, \uparrow \text { Bcl-w, } \\
\uparrow \text { Bcl-xL, } \uparrow \text { survivin, } \\
\downarrow \text { BAD, } \downarrow \text { BAX, } \\
\downarrow \text { PUMA }\end{array}$ & [102] \\
\hline $\begin{array}{l}\text { Human } \mathrm{BC}(\mathrm{MCF}-7) \text { tamoxifen } \\
\text { resistant cells }\end{array}$ & $\operatorname{miR}-221 / 222$ & $\begin{array}{l}\text { Human BC (MCF-7) } \\
\text { wild type cells }\end{array}$ & $\begin{array}{l}\uparrow \text { Resistance to } \\
\text { tamoxifen }\end{array}$ & $\downarrow \mathrm{P} 27, \downarrow \mathrm{ER} \alpha$, & [103] \\
\hline $\begin{array}{l}\text { Human cisplatin resistant } \\
\text { A549 cells }\end{array}$ & miR-100-5p & Human A549 cells & $\begin{array}{l}\uparrow \text { Resistance to } \\
\text { cisplatin }\end{array}$ & $\uparrow \mathrm{mTOR}$ & {$[104]$} \\
\hline $\begin{array}{l}\text { Gemcitabine treated human } \\
\text { PDAC CAFs }\end{array}$ & Snail and miR-146a & $\begin{array}{l}\text { Human pancreatic } \\
\text { cancer L3.6pl cells }\end{array}$ & $\begin{array}{l}\uparrow \text { proliferation, } \\
\uparrow \text { resistance to } \\
\text { gemcitabine }\end{array}$ & $\uparrow$ Snail, $\uparrow \mathrm{miR}-146 \mathrm{a}$ & {$[105]$} \\
\hline $\begin{array}{l}\text { Human HER-2-positive BC } \\
\text { trastuzumab resistant (SKBR-3 } \\
\text { and BT474) cells }\end{array}$ & $\begin{array}{c}\text { lncRNA } \\
\text { AFAP1-AS1 }\end{array}$ & $\begin{array}{l}\text { SKBR-3 and } \\
\text { BT474 cells }\end{array}$ & $\begin{array}{l}\uparrow \text { Resistance to } \\
\text { trastuzumab }\end{array}$ & $\uparrow$ ERBB2 & {$[106]$} \\
\hline $\begin{array}{l}\text { Tamoxifen resistant BC } \\
\text { (LCC2) cells }\end{array}$ & lncRNA UCA1 & $\begin{array}{l}\text { ER-positive BC } \\
\text { MCF-7 cells }\end{array}$ & $\begin{array}{l}\uparrow \text { Cell viability, } \\
\uparrow \text { resistance to } \\
\text { tamoxifen }\end{array}$ & $\downarrow$ caspase-3 & {$[107]$} \\
\hline $\begin{array}{l}\text { Human GC (MGC-803 and } \\
\text { MKN-45) cisplatin resistant cells }\end{array}$ & lncRNA HOTTIP & $\begin{array}{l}\text { MGC-803 and } \\
\text { MKN-45 cells }\end{array}$ & $\begin{array}{l}\uparrow \text { Resistance to } \\
\text { cisplatin }\end{array}$ & $\uparrow$ HMGA1 & {$[108]$} \\
\hline
\end{tabular}

Symbols: $\uparrow$, upregulated; $\downarrow$, downregulated; Abbreviations: AFAP1-AS1, actin filament associated protein1 antisense RNA 1; Akt, protein kinase B; Bad, Bcl-2 associated agonist of cell death; Bax, Bcl-2-associated X protein; Bcl-2, B-cell lymphoma 2; c-Met, Mesenchymal-epithelial transition factor; CXCL12, C-X-C motif chemokine ligand 12; CXCR4, C-X-C chemokine receptor type 4; Er $\alpha$, estrogen receptor- $\alpha$; ERF, Ets2-repressor factor; ERBB2, erythroblastic oncogene B; HGF, hepatocyte growth factor; HMGA1, High-mobility group A1; HOTTIP, HOXA transcript at the distal tip; MCP-1, monocyte chemoattractant protein-1; MMP, matrix metalloproteinase; NF- $\mathrm{B}$, nuclear factor kappa-light-chain-enhancer of activated B cells; PDCD4, programmed cell death 4; PI3K, phosphoinositide 3-kinase; PPP2R2A, protein phosphatase 2 regulatory subunit B alpha; PTEN, phosphatase and tensin homolog; PUMA, p53 upregulated modulator of apoptosis; sFRP, secreted frizzled-related protein 1 ; STAT, signal transducer and activator of transcription; Sox-2, sex determining region Y-box 2 ; TGF- $\beta$, transforming growth factor- $\beta$; TLR-2, toll-like receptor 2 ; TP53, tumor protein p53.

\subsection{Exosomes and Drug Resistance}

Exosomes form a physical barrier against drug penetration and confer drug resistance by transfer of cargoes from resistant to sensitive cells [104]. Exosome-mediated drug resistance may be devised through trafficking of non-coding RNAs, drug transporters and neutralization of antibody-based drugs, which has been described in the following sections.

\subsubsection{By Trafficking of Non-Coding RNAs}

Non-coding RNAs, including miRNAs and lncRNAs, perpetuated drug resistance across an array of cancer cells. Exosomes from M2-macrophage exerted miR-21-mediated upregulation of PI3K/Akt signaling and reduced apoptosis and cisplatin resistance in GC [93]. Exosomal miR-221/222 modulated p27 and ER $\alpha$ for tamoxifen resistance [103] in BC cells. Exosomes derived from cisplatin resistant cells induced resistance in cisplatin sen- 
sitive A549 cells in a miR-100-5p-dependent manner [104]. In ovarian cancer cells, exosomal miR-443 induced senescence and resistance against paclitaxel [109]. In prostate cancer, CAF derived exosomes conferred gemcitabine resistance via Snail and miR-146a [105]. Exosomal cargo-lncRNA UCA1 mediated tamoxifen resistance [107] and lncRNA actin filament associated protein 1 antisense RNA 1 (AFAP1-AS1) conferred trastuzumab resistance by binding to AU binding factor 1 and translating erythroblastic oncogene B2 (ERBB2) [106] in BC cells. MSC-derived exosomes aided the transfer of lncRNA PSMA3-AS1 to myeloma cells and exerted resistance against proteasome inhibitor [110]. In GC, exosomal lncRNA HoxA transcript at a distal tip (HOTTIP) made sensitive GC cells cisplatin resistant [108].

\subsubsection{By Trafficking of Drug Transporters and Neutralizing Antibody-Based Drugs}

The exosome-mediated transfer of drug transporter molecules is intimately associated with the spread of drug resistance across diverse cancer forms. Exosomes transported Pglycoprotein (P-gp) from doxorubicin-resistant cells [68] and multidrug resistance protein-1 (MDR-1) from docetaxel-resistant cells [111] to confer drug resistance in sensitive BC cells. Recently, it has been evidenced that exosome-mediated transfer of chloride intracellular channel 1 upregulated P-gp and B cell lymphoma-2 (Bcl-2) and conferred vincristine resistance in GC cell line SGC-7901 [112].

B-cell lymphoma derived exosomes modulated ATP-binding cassette (ABC) transporter A3, carried CD20 antigen which shielded the cancer cells against therapeutic CD20 antibodies and evaded immune surveillance [113]. Exocytosis of TEXs from human epidermal growth factor receptor 2 (HER2) positive BC cells expressed specific decoy molecules and conferred resistance against monoclonal antibody trastuzumab, thus depicting that TEXs are also involved in neutralizing antibody based drugs [114].

\section{Strategies against Tumor-Derived Exosomes}

There have been, primarily, three approaches for the management of exosomes associated with pathogenesis, as described below.

\subsection{Suppression of Exosome Biogenesis and Trafficking}

Genetic knockdown of tumor suppressor TSG1 (protein involved with exosome biogenesis and trafficking) reduced Wnt5b-positive exosomes in colon cancer [115]. Suppression of annexin A1 (responsible for membrane contact sites, inward vesiculation and exosome biosynthesis) reduced the number of secreted exosomes in pancreatic cancer cells [116]. Manumycin A was reported to inhibit ESCRT-dependent exosome biogenesis by modulating Ras/Raf/ERK1/2/heterogeneous nuclear ribonucleoprotein $\mathrm{H} 1$ axis in prostate cancer cells [117].

Small molecule inhibitor GW4869 against nSMase2 reduced secretion of ceramide enriched exosomes [118] and sensitized breast tumors by inhibition of exosomal PD-L1 [119]. Knockout of nSMase2 reduced exosome secretion, angiogenesis and metastasis in breast tumors [120]. Another inhibitor of lipid metabolism, pantethine, a pantothenic acid (vitamin $\mathrm{B}_{5}$ ) derivative, depleted the release of exosomes in MCF-7 variants and increased doxorubicin responsiveness [121]. Genetic silencing of Rab27A/B reduced exosomal secretion by HNSCC and macrophages, thereby minimizing metastasis in BC cells [76] and lung metastasis in melanoma [122]. PRAS40 downregulated Akt, downstream of TGF$\beta$, and mediated antagonistic effects against exosome secretion and chemoresistance in breast and lung cancer cells [123]. WEB2086, a platelet-activating factor receptor (PAFR) antagonist, was shown to reduce gemcitabine-induced exosome release in PAFR-positive pancreatic cancer cells [124]. Other exosome extrusion inhibitors, such as chloramidine, bisindolylmaleimide-I, imipramine, d-pantethine, and calpeptin, and calcium chelators, such as ethylene glycol bis (2-aminoethyl ether) tetra-acetic acid, increased responsiveness toward 5-FU in prostate and BC cells [125]. The inhibition of protease-activated receptor 2 by an anticoagulant, apixaban, which binds to the tissue factor-factor VIIa complex, downregulated the secretion of TF-bearing exosomes from pancreatic cancer 
cells [126]. Dasitinib inhibited exosome release and beclin-1/Vps34 mediated autophagy in imatinib resistant K562 cells [127]. Reduced exosome secretion by synthetic peptide (constructed with a derivative of the secretion modification region of HIV-1 Nef protein, a $\mathrm{N}$-terminus anchored polyethylene glycol residue and a c-terminus cluster in peptide) [128] and by Docosahexaenoic acid (a polyunsaturated fatty acid) [34] inhibited metastasis and angiogenesis, respectively, in BC cells.

\subsection{Depletion of Exosome Uptake}

A synthetic nanoparticle, which is a prototype of high-density lipoprotein, was used as an agonist of the scavenger receptor type B-1 (SR-B1) which eliminated cholesterol from lipid rafts and prevented exosome uptake by SR-B1 expressing cancer cells [129]. Other agents, such as heparin sulfate proteoglycans, methyl- $\beta$ cyclodextrin (molecule used for cholesterol removal from natural and artificial membranes) and dynasore (dynamin inhibitor), have been reported to abrogate exosome endocytosis in cancer cells [130]. Heparin and dynasore attenuated the uptake of multiple myeloma-derived exosome by bone marrow stromal cells and inhibited phosphorylation of STAT1, STAT3, and ERK1/2 signaling pathways [131]. Radiation-derived exosomes made the recipient cancer cells radiation-resistant and aggravated proliferation. Heparin and simvastatin attenuated radiation-derived exosome uptake by recipient cells in in vitro and in vivo models of glioblastoma [132].

\subsection{Modulation of Harmful Exosomal Cargo and Inhibition of Exosome Dissemination}

Alteration of exosomal cargoes was achieved by viral manipulation or by incorporation of viral proteins/RNA into secreted exosomes [133]. Curcumin culminated the immunosuppressive effect of exosomes in $\mathrm{BC}$ by deregulation of the ubiquitin-proteasome system and cargo sorting of ILVs [134]. Subscapular sinus CD169+ macrophages bound with exosomes restricted their interaction with B cells, promoting tumor progression [135]. Exosome release was inhibited by inhibitors like indometacin (COX2 inhibitor) in combination with rapamycin (interfere with MVB biogenesis) in B lymphoma cells, by suppressing ATP-binding cassette sub-family A member 3 expression of the lymphoma cells and induced the cells to undergo complement dependent cytolysis under the effect of drug rituximab [113].

\subsection{Removal of Exosomes}

A microfluidics-based technology-microscale acoustic standing wave technology facilitates clearance of exosomes from circulation [136]. Innate immune system in co-operation with opsonization effects of complement proteins may be used for elimination of exosomes [137]. Opsonization of exosomal markers CD9 and CD63 by targeting anti CD9 and anti CD63 antibodies elevated exosomes representation to the macrophages, leading to exosomes' elimination, which suppressed lung metastasis in vivo [138]. In colorectal cancer, dimethyl amiloride depleted exosomes, thereby elevating cyclophosphamide efficacy against the cancer cells [139].

\section{Cancer Management with Exosomes}

Exosomes have emerged as a new arena of clinical interest due to their prospective use in diagnostic applications as potential biomarkers, for carrying specific information of their progenitor cells, as well as for being ideal candidates for liquid biopsy [56].

\subsection{Preclinical Studies on Anticancer Potential of Exosomal Cargoes}

Uptake of exosomal contents does not always confer procarcinogenic signaling. There are instances where exosomal proteins promoted anticarcinogenic signaling pathways, e.g., exosomal uptake with payload of gastrokine1 suppressed H-Ras/Raf/MEK/ERKmediated gastric carcinogenesis in gastric epithelial cells [140]. The miR-375 carried by exosomes inhibited cell proliferation and invasive capability in colon cancer cells through 
Bcl-2 blocking [141]. Exosomal miR-520b derived from normal fibroblasts cells inhibited proliferation and migration of pancreatic cancer cells [142]. The migratory behavior of lung cancer cells was reduced by exosomal miR-497 through suppression of growth factors, cyclin E1 and VEGF [143]. Exosomal circulating RNA circ-0051443 inhibited tumor progression through apoptosis induction in HCC cells [144]. In BC cells, exosomal miR-100 derived from MSCs inhibited angiogenesis in vitro via modulating mTOR/HIF-1 $\alpha /$ VEGF signaling [145].

\subsection{Exosomes as Biomarkers}

Cancer cells secrete exosomes ten times higher than normal cells, which makes TEXs major potential candidates for liquid biopsy needed for cancer diagnosis and prognosis [57]. The release of exosomes in the extracellular space also aids in cancer diagnosis by examining their increased levels in various body fluids, such as blood, ascites fluid, urine, and saliva [146]. Exosomal DNA represents the entire genome; therefore, liquid biopsies of plasma aid in early detection of cancer-specific mutations. Exosomal CD63 and caveolin-1 served as non-invasive markers of melanoma [121]. Exosomal lncRNA, either with miR-21 or alone, was correlated with tumor classification (III/IV), stage of tumor and lymph node/distant metastasis in many cancer types [5]. Differential expression of exosomal miR-150, miR-155, and miR-1246 in serum of normal individuals and acute myeloid leukemia patients detected minimal residual disease [147]. Phosphatidylserine present on the exosomal surface also serves as a biomarker for diagnosis of early-stage cancer [148]. However, exosomal biomarkers are often overshadowed by highly prevalent complex proteins of the body fluids. Exosome isolation from body fluids follows either of the three methods, namely differential centrifugation coupled with ultracentrifugation, immunoaffinity pull-down, and density gradient separation. Mining of exosomal biomarkers from body fluid of cancer patients has been explored with fluorescence-based analytical techniques, electrochemical aptamer-based detection methods, localized surface plasmon resonance and surface-enhanced Raman scattering [149]. Though exosome biomarker analysis has tremendous translational potential, a gold standard for exosome isolation under clinical settings is yet to be achieved [150]. Since there is no definite consensus for isolation of exosomes, the best suitable body fluid for exosome isolation is also under investigation.

\subsection{Role of Exosomes in Immunotherapy and Vaccine Development}

DCs and other antigen presenting cells (APCs) derived exosomes are loaded with specific drugs; miRNAs of interest or even exosomes alone are implemented to trigger immune response in the recipient individuals (Figure 4). DC-based exosomes, in therapy, are beneficial as they possess abundant surface lactadherin that helps in efficient exosome uptake [151]. The functional moieties, such as MHC-I, MHC-II, CD40, CD80, CD86 TNF, FasL, TRAIL and natural killer group 2D (NKG2D) ligands on the surface of DC-derived exosomes, facilitate in imparting innate and adaptive antitumor immune response [152]. DC-derived exosomes activated NK cells in NKG2D and interkeukin (IL)-15R $\alpha$ ligand dependent mode, which restored $50 \%$ functionality of NK cells and was implemented as a cell free vaccination strategy [153]. The administration of adjuvants, such as IFN- $\gamma$, Tolllike receptor agonists, and polyinosinic: polycyctidylic acid, was explored for production of mature DC-derived exosomes which showed greater potential for activation of Th1 cells [154,155]. Immunogenic cell death was induced by melphalan, an anticancer drug, in multiple myeloma cells by increasing the damage-associated molecular pattern containing exosomes, thus triggering NK cell cytotoxicity [156]. A histone deacetylase inhibitor, MS275, increased the release of Hsp70 and MHC-I polypeptide-related sequence B (MICB)-rich exosomes which induced NK cytotoxicity and lymphocyte proliferation [157]. Heat shock treatment increasing the immunostimulatory activities of TEXs has been demonstrated in A20 lymphoma/leukemia cells. Heat shock tumor derived exosomes were observed to possess more immune-stimulating activities due to elevated expression of MHC and increased levels of cytokines, such as IL-1 $\beta$, IL-12p40, and TNF- $\alpha$ [158]. 


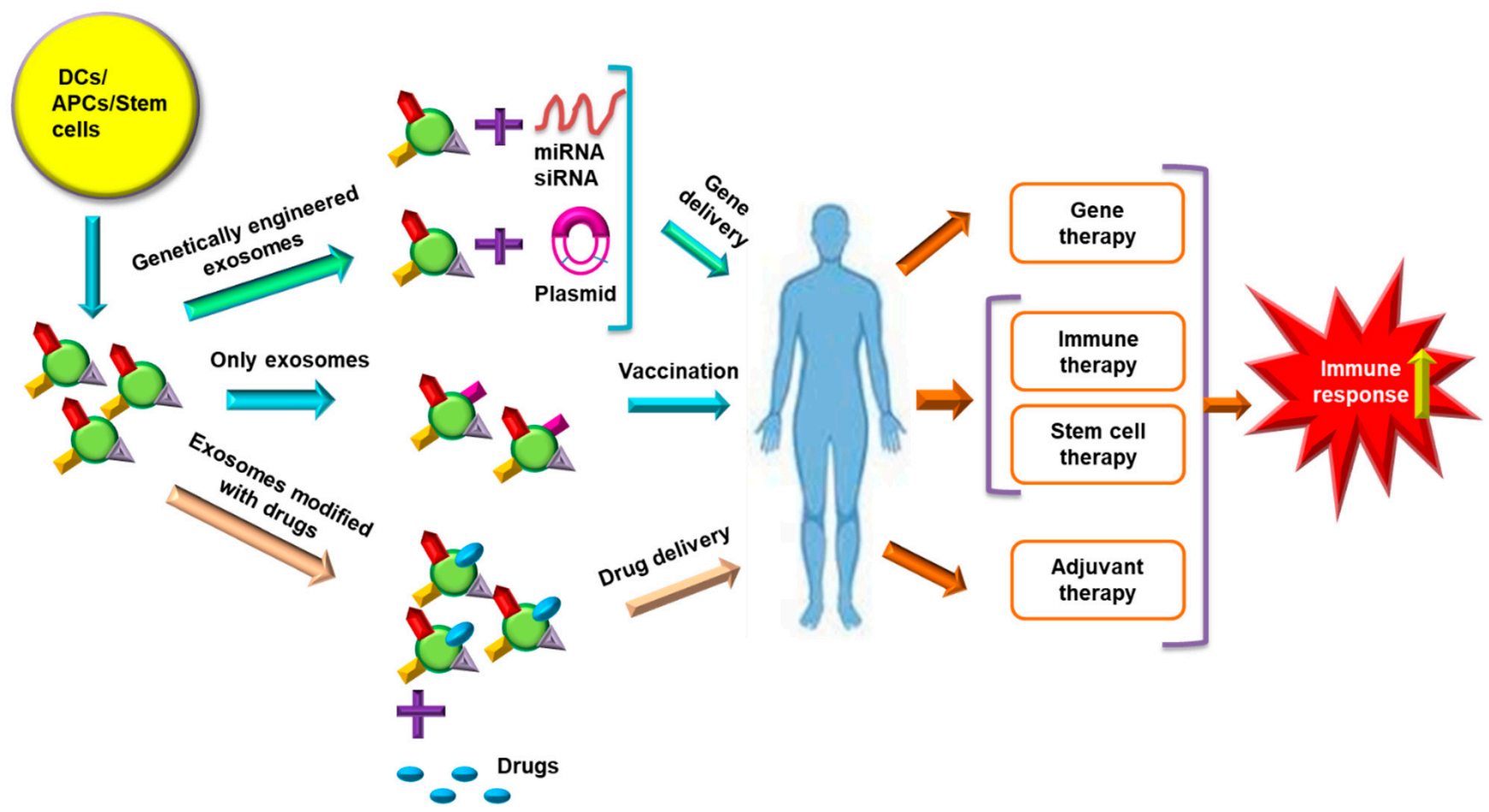

Figure 4. Exosomes in therapeutic approaches. Exosomes derived from DCs, APCs and stem cells can be utilized for immunotherapy, gene therapy, stem cell therapy and adjuvant therapy. Exosome based gene therapy is obtained by genetically engineered exosomes loaded with miRNA, siRNA and plasmids of interest. Stem cell or DC-derived exosomes can be implemented alone as vaccines and confer stem cell-based therapy or immunotherapy. The exosomes can also be utilized for drug delivery vectors by modifying them with drugs of interest. The DC-, APC- and stem cell-derived exosomes administered into the patient help in triggering immune response in combating cancer by targeting and regulating the mechanisms against which the exosomes are implemented. Abbreviations: APCs, antigen presenting cells; DCs, dendritic cells; miRNA, microRNA; siRNA, small interfering RNA.

Exosomes have potential use in vaccine development because the surface-bound proteins on exosomes of APCs, DCs and tumor cells originate from the progenitor cell membranes [5]. Nanoscale immunotherapy treatments with TEX, DC-derived exosomes and ascitic cell-derived exosomes have shown efficacy in stimulating the body's immune system against cancer cells [159]. Ascitic cell-derived exosomes obtained from peritoneal cavity fluid of cancer patients triggered cancer cell lysis via activation of dendritic cells and MHC-1-dependent T cell response. Membrane-bound Hsp70 of TEX exhibited robust priming of T helper cell 1 (Th1)- and NK-mediated antitumor immune response [160]. Chemotherapy accompanied with hyperthermia has evolved as a new treatment mode for cancer involving TEXs. For instance, heat stress has increased the antitumor effect of TEXs derived from doxorubicin-treated MCF-7 cells [161]. DC-derived exosomes control tumor growth by eliciting CD8+ and CD4+ T cell responses [162]. DC-derived exosomes incubated with cancer antigen triggered cancer specific $\mathrm{T}$ cell response [163]. Adjuvant-based exosomal vaccines are effective in eliciting immune response. For example, streptavidinlactadherin protein fused with immunostimulatory biotinylated CpG DNA (adjuvant) after transfection into murine melanoma cells created genetically modified exosomes. These exosomes have the ability to trigger improved antigen presentation to the DCs and other immune cells, contributing to enhanced immune response [164]. DC-derived exosomes have been observed to be more efficient as cell-free vaccines in treating malignancies that respond poorly to immunotherapy. For instance, $\alpha$-feto protein-rich DC derived exosomes triggered more effective antitumor immune responses and modulated the TME in a HCC mice model [165]. Recently, it was observed that vaccination with TEX-pulsed DC along with cytotoxic drugs specifically targeted immunosuppressive MDSCs in pancreatic cancer 
cells [166]. DNA vaccines prepared by fusing ovalbumin antigen with lactadherin present on exosomal surface diminished fibrosarcoma, thymoma and melanoma metastasis by activating T lymphocytes [167].

\subsection{Exosome-Based RNA Therapy}

Exosome-based miRNA therapy exhibited immunosuppressive properties by controlling the gene expressions [19]. An early study reported that exosomes derived from human embryonic kidney cells were effective in regressing tumor growth by delivering miR-let7a in an EGFR-positive BC xenograft model [168]. The MSCs transfected with miR-124a enhanced exosomes carrying the RNA of interest production, which, when implemented against gliomas, reduced the cell viability and targeted FOXA2 that caused accumulation of lipids [169]. Transfer of lncRNA PTEN pseudogene 1 by exosomes derived from normal cells to bladder cancer cells reduced tumor progression in vitro and in vivo [170].

Exosomes also mediated targeted delivery of siRNA, e.g., siRNA transfected into exosomes targeted RAD51 and RAD52 in Hela and fibrosarcoma cells, which inhibited proliferation of the recipient cells [171]. Engineered exosomes containing IL-3 ligand or functional siRNA for BCR-ABL were successfully used against imatinib resistance in chronic myeloid leukemia patients [172]. Exosomes used for trafficking RNA interference (RNAi) mediators counteracted against oncogenic KRAS and improved overall survival in mouse models of pancreatic cancer [173]. Delivery of engineered exosome mediated siRNA inhibited post-operative metastasis of BC, indicating a promising strategy against tumor progression [174]. Successful delivery of antisense miRNA oligonucleotides against miR- 21 by electroporating them in exosomal membrane improved the treatment efficacy for glioblastoma by inducing the expression of PTEN and PDCD4, resulting in decreased tumor size [175].

\subsection{Exosomes in Stem Cell Therapy}

Normal stem cell-derived exosomes are free of tumorigenic factors and are potential candidates for stem cell therapy [176]. MSC-derived exosomes can protect their cargoes from degradation, facilitate easier uptake by recipient cells, elicit low toxicity and immunogenicity, and these exosomes can be modified to enhance cell type-specific targeting and may be a prospective tool for cell-free based therapeutic approaches [177]. Exosomal miR144 derived from bone marrow derived MSC retarded the spread of NSCLC by targeting cyclin E1 or E2 [178]. Exosomes released from miR-101-3p overexpressing MSCs negatively affected the proliferation and migration of oral cancer cells by targeting the collagen type $X$ $\alpha 1$ chain [179]. MSC-derived exosomes were genetically engineered by loading them with polo-like kinase 1 (PLK-1)-siRNA and were utilized for PLK1 gene silencing in bladder cancer [180]. The primary hurdles of stem cell-based therapy, such as teratoma formation and embolization, are less frequent with exosome-based stem cell therapeutics. Exosomes secreted from induced pluripotent stem cells may exert better therapeutic effects [163].

\subsection{Exosomes in Drug Delivery}

Normal cell derived exosomes exhibit excellent biodistribution, biocompatibility, low immunogenicity, capacity to cross the blood-brain barrier and high target specificity, which make them potential candidates for drug delivery in cancer [5]. The exosomal surface proteins regulate efficient drug delivery because of their involvement in exosomes uptake by the tumorigenic recipient cells [181]. Exosomes derived from androgen-sensitive human prostate adenocarcinoma cells carrying paclitaxel negatively affect the cancer cells ${ }^{\prime}$ viability [182]. DC-derived exosomes in BC and macrophage-derived exosomes in lung cancer were loaded with the drugs trastuzumab and paclitaxel, respectively, and successfully delivered to the recipients $[183,184]$. Moreover, exosomes loaded with doxorubicin conjugated with gold nanoparticles showed anticancer effect against lung cancer cells [185]. Exosomes with A disintegrin and metalloproteinase 15 (ADAM15) expression (A15-Exo) co-delivered with doxorubicin and cholesterol-modified miRNA 159 exhibited anticancer 
effect in BC cells [186]. Paclitaxel loaded exosomes showed sensitivity towards MDR cancer cells via by-passing P-gp-mediated drug efflux and also inhibited metastasis in a lung cancer xenograft model [187]. Unmodified exosomes encapsulated with doxorubicin reduced tumor proliferation in a mouse mammary carcinoma xenograft model [137]. Exosomal delivery of doxorubicin induced its therapeutic activity in xenograft models of breast and ovarian cancer [188]. Exosomes isolated from engineered immature DCs (expressed Lamp2b fused with $\alpha v$ integrin-specific iRGD peptide (CRGDKGPDC)) loaded with doxorubicin successfully targeted $\alpha \mathrm{v}$ integrin-positive breast tumor cells [189]. Exosome encapsulated gemcitabine exhibited anticancer properties in autologous pancreatic cancer cells and in a xenograft model [190].

Phytochemicals, administered via an exosome-mediated drug delivery system, can provide health benefits and anticancer properties [56]. Pancreatic adenocarcinoma cellderived exosomes aided curcumin in inflicting its anticancer properties among tumor cells [191]. Milk-derived exosomes encapsulated with anthocyanidins exhibited antiproliferative effect in a xenograft lung carcinoma model [192]. Exosomal formulations of black bean extract exhibited pronounced antiproliferative effect in many cancer cells [193]. Exosomal formulations with berry anthocyanidins exhibited anticancer properties in ovarian cancer with enhanced sensitivity in chemoresistant tumors [194]. Exosomal encapsulation of celastrol (a triterpenoid) exhibited antiproliferative effect in lung cancer cells and in a xenograft model [195]. Recent studies on exosomal drug delivery of chemotherapeutic drugs and phytochemicals are listed in Table 3.

\subsection{Induction of Chemosensitivity with Exosomes}

TEXs impart drug resistance but may also be used for inducing drug sensitivity. Dimethyl amiloride augmented $\mathrm{ABC}$ transporter containing exosome secretion revived the cyclophosphamide sensitivity of cancer cells [31]. Downregulation of the GAIP-interacting protein $\mathrm{C}$ terminus mediated secretion of ABCG2 drug transporters containing exosomes and suppressed gemicitabine resistance in pancreatic cancer cells [196]. In oral squamous cell carcinoma, exosomal miR-155 increased chemoresistivity in cisplatin-sensitive cancer cells [197]. The exosomes loaded with CRISPR/Cas9 induced apoptosis and cisplatin chemosensitivity in ovarian cancer cells [198]. An increase in apoptosis and chemosensitivity was observed in cisplatin-resistant human gastric adenocarcinoma cells through treatment with si-c-Met containing exosomes derived from human kidney epithelial cell line [199]. Normal intestinal FHC cell-derived exosomes transferred miR-128-3p into oxiplatin resistant CRC cells which induced their chemosensitivity and decreased motility [200]. miR-122-transfected adipose tissue-derived MSCs (AMSCs) released exosomes carrying miR-122 and, when cocultured with hepatocyte carcinoma cells, induced sorafenib chemosensitivity [201]. miR-567 induced chemosensitivity in resistant BC cells towards trastuzumab and blocked autophagy [202]. Exosomal miR-200c induced chemosensitivity towards docetaxel and apoptosis in tongue squamous cell carcinoma [203]. Coculture of miR-199a carrying exosomes derived from AMSCs with HCC cells downregulated mammalian target of rapamycin (mTOR) pathway and induced chemosensitivity towards doxorubicin [204]. Various recent reports on exosome-mediated reversal of chemosensitivity have been listed in Table 4. 
Table 3. Exosomes as delivery system for therapeutic implications against cancer.

\begin{tabular}{|c|c|c|c|c|c|c|}
\hline Exosome Source & Modification of Exosomes with Drugs & Loading Method & Target Cells & Effect & Mechanism & References \\
\hline \multicolumn{7}{|c|}{ Chemotherapeutic drugs } \\
\hline $\begin{array}{c}\text { Human mammary } \\
\text { adenocarcinoma cells } \\
\text { (M-CF-7), mouse mammary } \\
\text { carcinoma cells (4T1), and } \\
\text { human prostate } \\
\text { adenocarcinoma cells (PC3) }\end{array}$ & Doxorubicin & Incubation & $\begin{array}{l}\text { 4T1 tumor-bearing } \\
\text { BALB /c mice }\end{array}$ & $\begin{array}{l}\quad \downarrow \text { Tumor growth, but no } \\
\text { significant reduction in tumor } \\
\text { growth with exosomes loaded } \\
\text { with doxorubicin compared to } \\
\text { free drug }\end{array}$ & - & [137] \\
\hline $\begin{array}{l}\text { Human prostate cancer } \\
\text { (LNCaP and PC-3) cells }\end{array}$ & Paclitaxel & Incubation & LNCaP and PC-3 cells & $\uparrow$ Cytotoxic effect of paclitaxel & - & [182] \\
\hline Human NSCLC (H1299) cells & Exo-gold nanoparticles-doxorubicin & Incubation & $\begin{array}{c}\text { Human NSCLC (H1299 and } \\
\text { A549) cells }\end{array}$ & $\uparrow$ DNA damage, $\uparrow$ apoptosis & $\uparrow$ caspase- $9, \uparrow$ ROS & [185] \\
\hline \multirow{2}{*}{$\begin{array}{l}\text { Human monocyte (THP-1 } \\
\text { cells)-derived macrophages }\end{array}$} & \multirow{2}{*}{ A15-Exo-doxorubicin-cho-miR159 } & \multirow{2}{*}{$\begin{array}{l}\text { Mixing in triethylamine } \\
\text { solution overnight, } \\
\text { Incubation }\end{array}$} & $\begin{array}{c}\alpha v \beta 3+\text { and } \alpha \mathrm{v} \beta 3-\text { human } \mathrm{BC} \\
\text { (MDA-MB-231 and } \\
\text { MCF-7) cells }\end{array}$ & $\downarrow$ Cell proliferation, $\uparrow$ apoptosis & $\downarrow \mathrm{TCF} 7, \downarrow \mathrm{MYC}$ & \multirow{2}{*}{ [186] } \\
\hline & & & $\begin{array}{l}\text { MDA-MB-231 tumor-bearing } \\
\text { BALB/c-nu mice }\end{array}$ & $\begin{array}{l}\downarrow \text { Tumor growth, } \uparrow \text { survival } \\
\text { of mice }\end{array}$ & $\downarrow \mathrm{TCF} 7, \downarrow \mathrm{MYC}, \downarrow \mathrm{Ki} 67, \downarrow \mathrm{CD} 31$ & \\
\hline $\begin{array}{l}\text { Mouse immature dendritic } \\
\text { cells (imDCs) }\end{array}$ & Doxorubicin & Electroporation & $\begin{array}{l}\text { MDA-MB-231 tumor-bearing } \\
\text { BALB/c nude mice }\end{array}$ & $\downarrow$ Tumor growth & - & [189] \\
\hline $\begin{array}{l}\text { Human pancreatic cancer } \\
\text { (Panc-1) cells }\end{array}$ & Gemcitabine & Sonication & $\begin{array}{l}\text { Panc-1 tumor-bearing } \\
\text { BALB/c nude mice }\end{array}$ & $\downarrow$ Tumor volume & $\begin{array}{c}\downarrow \text { Alanine aminotransferase, } \\
\downarrow \text { aspartate aminotransferase, } \\
\downarrow \text { TNF- } \alpha, \downarrow \text { IL-6 in } \\
\text { exo-gemcitabine group } \\
\text { compared to gemcitabine }\end{array}$ & [190] \\
\hline \multirow{2}{*}{$\begin{array}{l}\text { Mouse (RAW 264.7) } \\
\text { macrophages }\end{array}$} & \multirow{2}{*}{ Paclitaxel } & \multirow{2}{*}{ Sonication } & $\begin{array}{l}\text { Murine Lewis lung carcinoma } \\
\text { cell subline (3LL-M27 cells), } \\
\text { Madin-Darby canine kidney } \\
\text { (MDCK-WT) and } \\
\text { (MDCK-MDR1) cells }\end{array}$ & $\begin{array}{c}\uparrow \text { Drug cytotoxicity, } \\
\uparrow \text { chemosensitization of MDR } \\
\text { cells }\end{array}$ & - & \multirow{2}{*}{ [187] } \\
\hline & & & $\begin{array}{l}\text { 8FlmC-FLuc-3LL-M27 tumor } \\
\text { bearing C57BL/ } 6 \text { mice }\end{array}$ & $\downarrow$ Metastasis & - & \\
\hline $\begin{array}{l}\text { Human BC (MDA-MB-231) } \\
\text { cells and mouse ovarian } \\
\text { cancer (STOSE) cell }\end{array}$ & Doxorubicin & Electroporation & $\begin{array}{l}\text { MDA-MB-231 and STOSE } \\
\text { tumor bearing FVB/N mice }\end{array}$ & $\begin{array}{l}\uparrow \text { Doxorubicin efficacy, } \\
\downarrow \text { tumor volume }\end{array}$ & - & [188] \\
\hline
\end{tabular}


Table 3. Cont.

\begin{tabular}{|c|c|c|c|c|c|c|}
\hline Exosome Source & Modification of Exosomes with Drugs & Loading Method & Target Cells & Effect & Mechanism & References \\
\hline \multicolumn{7}{|c|}{ Phytochemicals } \\
\hline $\begin{array}{l}\text { Human pancreatic } \\
\text { adenocarcinoma (PANC-1, } \\
\text { MIA PaCa-2) cells }\end{array}$ & Curcumin & Incubation & PANC- 1 and MIA PaCa- 2 cells & $\downarrow$ Cell viability, & - & [191] \\
\hline \multirow{2}{*}{$\begin{array}{l}\text { Pooled raw milk from } \\
\text { Jersey cows }\end{array}$} & \multirow[t]{2}{*}{ Anthocyanidins } & \multirow{2}{*}{$\begin{array}{c}\text { By mixing in a solution of } \\
\text { acetonitrile: ethanol (1:1 } \\
v / v) \text { and PBS }\end{array}$} & $\begin{array}{c}\text { Human pancreatic cancer } \\
\text { (PANC1 and Mia PaCa2), lung } \\
\text { cancer (A549 and H1299), } \\
\text { colon cancer (HCT116), BC } \\
\text { (MDA-MB-231 and MCF7), } \\
\text { prostate cancer (PC3 and } \\
\text { DU145), and ovarian cancer } \\
\text { (OVCA432) cells }\end{array}$ & $\begin{array}{l}\downarrow \text { Cell proliferation, } \\
\downarrow \text { cell survival }\end{array}$ & $\downarrow N F-\kappa B$ & \multirow{2}{*}{ [192] } \\
\hline & & & $\begin{array}{l}\text { A549 tumor bearing female } \\
\text { athymic nude }(\mathrm{nu} / \mathrm{nu}) \text { mice }\end{array}$ & $\downarrow$ Tumor growth & - & \\
\hline $\begin{array}{l}\text { MCF7, PC3, human liver } \\
\text { (HepG2), colon cancer } \\
\text { (Caco2) cells }\end{array}$ & Black bean extract & Electroporation & $\begin{array}{l}\text { MCF7, PC3, HepG2 and } \\
\text { Caco2 cells }\end{array}$ & $\downarrow$ Cell viability & - & [193] \\
\hline \multirow[b]{2}{*}{ Mature bovine milk } & \multirow[b]{2}{*}{ Anthocyanidins } & \multirow[b]{2}{*}{ By mixing } & $\begin{array}{c}\text { Human ovarian cancer } \\
\text { (A2780, A2780/CP70, } \\
\text { OVCA432, and } \\
\text { OVCA433) cells }\end{array}$ & $\downarrow$ Cell survival & - & \multirow{2}{*}{ [194] } \\
\hline & & & $\begin{array}{l}\text { A2780 tumor-bearing female } \\
\text { athymic nude mice }\end{array}$ & $\downarrow$ Tumor volume & - & \\
\hline \multirow{2}{*}{$\begin{array}{l}\text { Milk from pasture-fed } \\
\text { Holstein and Jersey cows }\end{array}$} & \multirow{2}{*}{ Celastrol } & \multirow{2}{*}{ By mixing } & $\begin{array}{l}\text { Human lung cancer (H1299 } \\
\text { and A549) cells }\end{array}$ & $\downarrow$ Cell survival, & - & \multirow{2}{*}{ [195] } \\
\hline & & & $\begin{array}{c}\mathrm{H} 1299 \text { and A549 } \\
\text { tumor-bearing female athymic } \\
\text { nude mice }\end{array}$ & $\downarrow$ Tumor volume & - & \\
\hline
\end{tabular}

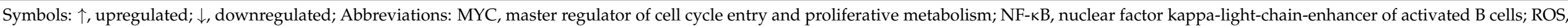
reactive oxygen species; TCF7, transcription factor 7; TNF- $\alpha$, tumor necrosis factor- $\alpha$. 
Table 4. Reversal of chemoresistance in resistant cancer cells with exosomal cargoes.

\begin{tabular}{|c|c|c|c|c|c|}
\hline Exosome Source & $\begin{array}{l}\text { Modification in Exosomal } \\
\text { Cargo Content }\end{array}$ & Target Cells & Effects & Mechanisms & References \\
\hline $\begin{array}{l}\text { Human mesenchymal } \\
\text { stem cells (MSCs) }\end{array}$ & Anti-miR-9 & $\begin{array}{c}\text { Glioblastoma (U87 and } \\
\text { T98G) cells }\end{array}$ & $\begin{array}{c}\uparrow \text { Apoptosis } \\
\uparrow \text { chemosensitivity } \\
\text { towards } \\
\text { temozolomide }\end{array}$ & $\begin{array}{c}\uparrow \text { Caspase-3 } \\
\downarrow \text { P-gp } \\
\downarrow \text { MDR1 }\end{array}$ & [151] \\
\hline $\begin{array}{l}\text { Human kidney } \\
\text { epithelial } \\
\text { (HEK293T) cells }\end{array}$ & si-c-Met & $\begin{array}{l}\text { Human gastric } \\
\text { adenocarcinoma } \\
\text { (SGC7901and } \\
\text { SGC7901/DDP) cells }\end{array}$ & $\begin{array}{c}\uparrow \text { Apoptosis } \\
\uparrow \text { chemosensitivity } \\
\text { towards cisplatin }\end{array}$ & $\downarrow c$-Met gene & [199] \\
\hline $\begin{array}{l}\text { Normal intestinal foetal } \\
\text { human cells (FHC) }\end{array}$ & miR-128-3p & $\begin{array}{l}\text { Human oxiplatin } \\
\text { resistant colorectal cancer } \\
\text { (HCT116OxR) cells }\end{array}$ & $\begin{array}{c}\uparrow \text { Oxiplatin } \\
\text { accumulation } \\
\uparrow \text { apoptosis } \\
\downarrow \text { proliferation } \\
\downarrow \text { self-renewal }\end{array}$ & $\begin{array}{c}\downarrow \text { Bmi1 } \\
\downarrow \text { MRP5 } \\
\downarrow \text { N-cadherin } \\
\uparrow \text { E-cadherin }\end{array}$ & [200] \\
\hline $\begin{array}{l}\text { Human adipose tissue } \\
\text { derived mesenchymal } \\
\text { stem cells (AMSCs) }\end{array}$ & miR-122 & $\begin{array}{c}\text { Human HCC (HepG2, } \\
\text { Huh7) cells }\end{array}$ & $\begin{array}{c}\uparrow \text { Apoptosis } \\
\uparrow \text { cell cycle arrest } \\
\uparrow \text { chemosensitivity } \\
\text { towards sorafenib }\end{array}$ & $\begin{array}{c}\uparrow \mathrm{G} 0 / \mathrm{G} 1 \text { arrest } \\
\downarrow \mathrm{CCNG} 1 \\
\downarrow \text { ADAM10 } \\
\uparrow \text { Caspase-3 } \\
\uparrow \text { Bax }\end{array}$ & [201] \\
\hline $\begin{array}{l}\text { Human normal breast } \\
\text { epithelial (MCF } \\
\text { 10A) cells }\end{array}$ & miR-567 & $\begin{array}{l}\text { Human trastuzumab } \\
\text { resistant BC (SKBR-3/TR } \\
\text { and BT474/TR) cells }\end{array}$ & $\begin{array}{c}\uparrow \text { Chemosensitivity } \\
\text { towards trastuzumab } \\
\uparrow \text { autophagy }\end{array}$ & $\begin{array}{c}\downarrow \text { ATG5 } \\
\uparrow \text { p62 } \\
\downarrow \text { LC3-11 }\end{array}$ & [202] \\
\hline $\begin{array}{l}\text { Human normal tongue } \\
\text { epithelial (NTECs) cells }\end{array}$ & miR-200c & $\begin{array}{l}\text { Docetaxel resistant } \\
\text { hepatic stellate cells } \\
\text { (HSC-3DR) cells }\end{array}$ & $\begin{array}{c}\uparrow \text { Chemosensitivity } \\
\text { towards docetaxel } \\
\uparrow \text { apoptosis }\end{array}$ & $\begin{array}{c}\downarrow \text { TUBB3 } \\
\downarrow \text { PPP2R1B }\end{array}$ & [203] \\
\hline $\begin{array}{l}\text { Human adipose tissue } \\
\text { derived mesenchymal } \\
\text { stem cells (AMSCs) }\end{array}$ & miR-199a & $\begin{array}{c}\text { Human colorectal cancer } \\
\text { (CRC) (Huh7, } \\
\text { SMMC-7721, } \\
\text { PLC/PRF/5) cells }\end{array}$ & $\begin{array}{l}\uparrow \text { Chemosensitivity } \\
\text { towards doxorubicin }\end{array}$ & $\downarrow \mathrm{mTOR}$ & [204] \\
\hline
\end{tabular}

Symbols: $\uparrow$, upregulated; $\downarrow$, downregulated; Abbreviations: ADAM10, A disintegrin and metalloproteinase 10; ATG5, autophagy related 5 protein; Bax, Bcl-2-associated X protein; BC, breast cancer; c-MET, mesenchymal epithelial transition factor; CCNG1, Cyclin G1; LC3, microtubule associated protein PIA/IB-light chain 3-I; MDR1, multidrug resistance protein-1; MRP5, multidrug resistant associated protein 5; mTOR, mammalian target of rapamycin; P-gp, P-glycoprotein; PPP2R1B, protein phosphatase 2 scaffold subunit 1 $\beta$; TUBB3, class III $\beta$-tubulin gene.

\subsection{Exosomes in Clinical Trials}

According to the National Institutes of Health website, a large number of clinical trials are being conducted with exosomes (Table 5). In a study, plant exosomes were modified to deliver curcumin in colon cancer patients (ClinicalTrials.gov Identifier: NCT01294072). Phase I and II clinical trials with DC-derived exosomes indicated activation of T celland NK cell-based immune responses in NSCLC patients [154]. A phase II clinical trial (ClinicalTrials.gov Identifier: NCT01159288) on NSCLC observed that exosomes derived from TLR4L-or interferon- $\gamma($ IFN- $\gamma$ )-maturated DCs enriched with MHC I- and MHC II-restricted cancer antigens as maintenance immunotherapy subsequent to first-line chemotherapy [205]. A study on HER2-positive BC patients measured HER2-HER3 dimer expression in exosomes (ClinicalTrials.gov Identifier: NCT04288141). Another trial led to a therapeutic analysis on cancer-derived exosomes via treatments with lovastatin and vildagliptin in thyroid cancer patients (ClinicalTrials.gov Identifier: NCT02862470). Characterization of exosomal non-coding RNAs was carried out in cholangiocarcinoma patients (ClinicalTrials.gov Identifier: NCT03102268). Another study reported exosome-mediated intercellular signaling in pancreatic cancer (ClinicalTrials.gov Identifier: NCT02393703). In metastatic pancreatic adenocarcinoma, exosomes with KrasG12D siRNA were used to treat pancreatic cancer with KrasG12D mutation (ClinicalTrials.gov Identifier: NCT03608631). In head and neck cancer, the effects of metformin hydrochloride on cytokines and exosomes were investigated (ClinicalTrials.gov Identifier: NCT03109873). A phase I clinical trial 
(ClinicalTrials.gov Identifier: NCT01668849) investigated the ability of plant exosomes to prevent oral mucositis induced by combined chemotherapy and radiation in head and neck cancer patients. However, more clinical trials are needed with modified exosomes which may exhibit anticancer effect.

Table 5. Clinical trials on exosomes.

\begin{tabular}{|c|c|c|c|c|c|}
\hline $\begin{array}{c}\text { Trial No. } \\
\text { (ClinicalTrials.gov } \\
\text { Identifier:) }\end{array}$ & Study Type & Cancer Type & Study Perspective & Study Design & Status \\
\hline NCT01294072 & Phase I & Colon cancer & Interventional & $\begin{array}{c}\text { Investigation of the ability of } \\
\text { plant-derived exosomes to } \\
\text { deliver curcumin }\end{array}$ & Active, not recruiting \\
\hline NCT01159288 & Phase II & $\begin{array}{l}\text { Non-small cell } \\
\text { lung cancer }\end{array}$ & Interventional & $\begin{array}{l}\text { Trial of a vaccination with } \\
\text { exosomes derived from } \\
\text { dendritic cell loaded with } \\
\text { tumor antigen }\end{array}$ & Completed \\
\hline NCT04288141 & Observational & $\begin{array}{c}\text { Early } \\
\text { HER2-positive } \\
\text { BC, Metastatic } \\
\text { HER2-positive } \\
\text { BC }\end{array}$ & Prospective & $\begin{array}{l}\text { Assessment of HER2-HER3 } \\
\text { dimer expression in exosomes } \\
\text { from HER2-positive patients } \\
\text { receiving HER2 targeted } \\
\text { therapies }\end{array}$ & Recruiting \\
\hline NCT02862470 & Observational & $\begin{array}{c}\text { Anaplastic } \\
\text { thyroid cancer, } \\
\text { Follicular thyroid } \\
\text { cancer }\end{array}$ & Prospective & $\begin{array}{l}\text { Analysis of cancer-derived } \\
\text { exosomes via lovastatin and } \\
\text { vildagliptin treatments and } \\
\text { prognostic study through } \\
\text { urine exosomal markers }\end{array}$ & Active, not recruiting \\
\hline NCT03102268 & Observational & Cholangiocarcinoma & Prospective & $\begin{array}{l}\text { Characterization of exosomal } \\
\text { non-coding RNAs from } \\
\text { cholangiocarcinoma patients } \\
\text { before anticancer therapies }\end{array}$ & Unknown \\
\hline NCT02393703 & Observational & Pancreatic cancer & Prospective & $\begin{array}{l}\text { Investigation of exosome } \\
\text { mediated disease recurrence }\end{array}$ & Active, not recruiting \\
\hline NCT03608631 & Phase I & $\begin{array}{c}\text { Metastatic } \\
\text { pancreatic } \\
\text { adenocarcinoma, } \\
\text { Pancreatic ductal } \\
\text { adenocarcinoma }\end{array}$ & Interventional & $\begin{array}{l}\text { Study of the mesenchymal } \\
\text { stromal cells-derived } \\
\text { exosomes with KrasG12D } \\
\text { siRNA (iExosomes) for } \\
\text { pancreatic cancer patients } \\
\text { having KrasG12D }\end{array}$ & Not yet recruiting \\
\hline NCT03109873 & Early phase I & $\begin{array}{l}\text { Head and neck } \\
\text { cancer }\end{array}$ & Randomized & $\begin{array}{l}\text { Assessment of the effect of } \\
\text { metformin hydrochloride on } \\
\text { cytokines and exosomes in } \\
\text { cancer patients }\end{array}$ & Completed \\
\hline NCT01668849 & Phase I & $\begin{array}{l}\text { Head and neck } \\
\text { cancer }\end{array}$ & Interventional & $\begin{array}{l}\text { Investigation of the ability of } \\
\text { plant-derived exosomes to } \\
\text { prevent oral mucositis } \\
\text { induced by combined } \\
\text { chemotherapy and radiation }\end{array}$ & Active, not recruiting \\
\hline
\end{tabular}

\section{Current Limitations and Challenges}

Exosomes mediate intercellular communication and play significant roles in both physiological and pathological processes. A new hypothesis suggested that the target cells inhibit the incoming signals by forming exosome dimers based on the particle size, zeta potential and/or ligand-receptor pairs which facilitates cancer metastasis, cancer immunoregulation, intraocular pressure homoeostasis, tissue regeneration and many others [206].

Exosomes released by normal and malignant cells are endowed with heterogeneity and pleiotropic physiological and pathological effects. Inhibition of the release of TEXs may have both anti-carcinogenic and pro-carcinogenic effects. The majority of the exosome released inhibitors are not cancer-specific and also affect normal cells. Therefore, 
inhibition of exosome release may act as a double-edged sword which should be carefully manipulated for minimal adverse effects [34].

Isolation of pure and specific exosomes is limited by technical constraints, the availability of suitable biomarkers for specific exosomes, and expensive technologies [5]. A major hurdle in the execution of liquid biopsy is isolation of exosomes by an economic userfriendly tool. Protein contaminated and heterogenous exosome pool is obtained using ultracentrifugation. Asymmetric flow field-flow fractionation, though a prospective tool, needs technical expertise and requires a huge amount of initial sample. Other exosome isolation methods like microfluidic devices, sucrose gradients, size exclusion chromatography, and affinity-based exosome isolation kits are accompanied with both advantages and disadvantages like lack of robustness and specificity [31]. A perfect exosome isolation method should be robust, reproducible, specific, economic and user friendly as a diagnostic tool.

Detailed research of exosome biogenesis, functional diversity of exosomes and the identification of cancer specific biomarkers may be effective for exosome-based therapeutic approaches with minimum adverse effects [34]. Determination of exosomal cargo sorting and releasing mechanisms holds great potential for the development of various applications in cancer research [31].

Normally, less than $1 \mu \mathrm{g}$ of exosomal protein is yielded from $1 \mathrm{~mL}$ of culture medium, whereas the majority of studies have reported $10-100 \mu \mathrm{g}$ of exosomal protein as an effective dose for in vivo models [163]. The introduction of exosome-mimetic vesicles (100-200 nm in diameter) has conquered exosomal limitations like low loading efficiency and low yields. These nanovesicles have been used for delivery of chemotherapeutic drugs [204,205] and RNAi [207] to target cancer cells. Hybrid nanocarriers formed by the fusion of exosomes with liposomes changed the exogenous lipid composition and was effective in the delivery of chemotherapeutic drugs [208].

\section{Conclusions}

It may be deciphered that the intercellular communication via exosomes is evident throughout cancer progression. Apart from cancer pathogenesis, exosome biology heralds the future arena of non-invasive diagnostic tools for cancer management, especially in the spheres of liquid biopsy, immunotherapy and vaccine development, RNA therapy, stem cell therapy, drug delivery, and reversal of chemoresistance. Preclinical studies have undoubtedly proven the immense potential of exosomes in cancer therapeutics, but a number of clinical trials have failed to achieve this success. These inconsistent results indicate major challenges including in-depth knowledge of exosome biogenesis and protein sorting, perfect and pure isolation of exosomes, large scale production, better loading efficiency targeted delivery of exosomes. These hurdles have to be confronted before successful implementation of exosomes for the diagnosis and therapy of cancer. This review has attempted to envisage the implication of exosomes in cancer pathogenesis and cancer therapeutics along with the current limitations so that researchers may be made aware of the existing lacunae with regard to exosomes in their use against cancer. This knowledge may help scientists to improvise innovative technologies for successful translation of the exosome-mediated diagnosis and treatment of malignant neoplasms.

Author Contributions: Conceptualization and writing, D.S.; writing and figure preparation, S.R., P.S. and N.C.; editing and suggestion of improvements, A.B. All authors have read and agreed to the published version of the manuscript.

Funding: This research received no external source of funding.

Institutional Review Board Statement: Not applicable.

Informed Consent Statement: Not applicable.

Data Availability Statement: Not applicable. 
Acknowledgments: D.S., S.R., P.S., and N.C. are deeply grateful to Jayanta Chakrabarti, Director, Chittaranjan National Cancer Institute, Kolkata, for providing the infrastructural facilities. P.S. is thankful to Jayanta Chakrabarti for granting an institutional fellowship. S.R. is indebted to the University Grants Commission, New Delhi, India, for providing a fellowship.

Conflicts of Interest: The authors declare no conflict of interest.

\section{Abbreviations}

ABC ATP-binding cassette;

ABCA3 ATP-binding cassette sub-family A member 3;

ADAM10 A disintegrin and metalloproteinase 10;

AFAP1-AS1 actin filament associated protein1 antisense RNA 1;

Akt protein kinase B;

ALIX ALG-2 interacting protein $X$;

AMSCs adipose tissue-derived MSCs;

APC antigen presenting cell;

ARF6 ADP ribosylation factor 6;

ATG5 autophagy related 5 protein;

CAFs cancer-associated fibroblasts;

CCNG1 cyclin G1;

CRC colorectal cancer cells;

CXCR4 C-X-C chemokine receptor type 4;

DCs dendritic cells;

ECM extracellular matrix;

EGFR epidermal growth factor receptor;

EMT epithelial mesenchymal transition;

ERBB2 erythroblastic oncogene B2;

ERF Ets2-repressor factor;

ERK extracellular signal-regulated kinase;

$\mathrm{ER} \alpha \quad$ estrogen receptor- $\alpha$;

ESCRT endosomal sorting complexes required for the transport;

GC gastric cancer;

HCC hepatocellular carcinoma;

HER2 human epidermal growth factor receptor 2;

HGF hepatocyte growth factor;

HNSCC head and neck squamous cell carcinoma;

HOTTIP HoxA transcript at a distal tip;

Hsps heat shock proteins;

ICAM intercellular adhesion molecule;

IL-6 interleukin-6;

ILV intraluminal vesicles;

LAMP-1 lysosome-associated membrane glycoprotein-1 LncRNAs

LncRNAs long non-coding RNAs;

MAPK mitogen activated protein kinase;

MDR-1 multidrug resistance protein-1;

MDSCs myeloid-derived suppressor cells;

MHC major histocompatibility complex;

miRNAs microRNA:

MMP matrix metalloproteinase;

mRNA messenger RNA;

MSCs mesenchymal stem cells;

mtDNA mitochondrial DNA;

MVB multivesicular bodies;

NF- $\mathrm{B} \quad$ nuclear factor $\kappa$-light-chain-enhancer of activated B cells;

NK natural killer cells;

NKG2D natural killer group 2D; 


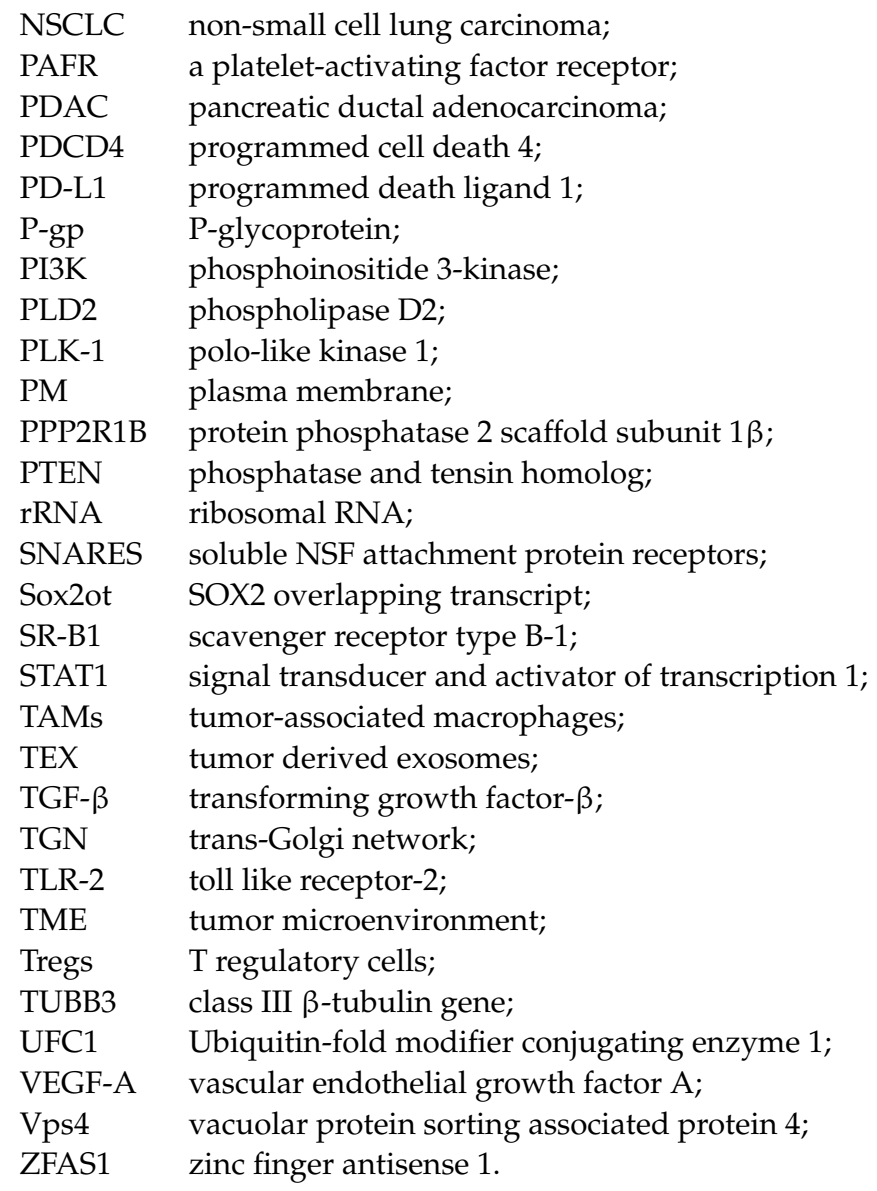

\section{References}

1. Harding, C.; Stahl, P. Transferrin Recycling in Reticulocytes: $\mathrm{pH}$ and Iron Are Important Determinants of Ligand Binding and Processing. Biochem. Biophys. Res. Commun. 1983, 113, 650-658. [CrossRef]

2. Lötvall, J.; Hill, A.F.; Hochberg, F.; Buzás, E.I.; Vizio, D.D.; Gardiner, C.; Gho, Y.S.; Kurochkin, I.V.; Mathivanan, S.; Quesenberry, P.; et al. Minimal experimental requirements for definition of extracellular vesicles and their functions: A position statement from the International Society for Extracellular Vesicles. J. Extracell. Vesicles 2014, 3, 26913. [CrossRef]

3. Théry, C.; Witwer, K.W.; Aikawa, E.; Alcaraz, M.J.; Anderson, J.D.; Andriantsitohaina, R.; Antoniou, A.; Arab, T.; Archer, F.; Atkin-Smith, G.K.; et al. Minimal information for studies of extracellular vesicles 2018 (MISEV2018): A position statement of the International Society for Extracellular Vesicles and update of the MISEV2014 guidelines. J. Extracell. Vesicles 2018, 7, 1535750. [CrossRef]

4. Zhang, C.; Ji, Q.; Yang, Y.; Li, Q.; Wang, Z. Exosome: Function and role in cancer metastasis and drug resistance. Technol. Cancer Res. Treat. 2018, 17. [CrossRef]

5. He, C.; Zheng, S.; Luo, Y.; Wang, B. Exosome theranostics: Biology and translational medicine. Theranostics 2018, 8, 237-255. [CrossRef]

6. McAndrews, K.M.; Kalluri, R. Mechanisms associated with biogenesis of exosomes in cancer. Mol. Cancer 2019, 18, 52. [CrossRef]

7. Jurj, A.; Zanoaga, O.; Braicu, C.; Lazar, V.; Tomuleasa, C.; Irimie, A.; Berindan-neagoe, I. A comprehensive picture of extracellular vesicles and their contents. Molecular transfer to cancer cells. Cancers 2020, 12, 298. [CrossRef]

8. Lucchetti, D.; Tenore, C.R.; Colella, F.; Sgambato, A. Extracellular Vesicles and Cancer: A Focus on Metabolism, Cytokines, and Immunity. Cancers 2020, 12, 171. [CrossRef]

9. Tang, Z.; Li, D.; Hou, S.; Zhu, X. The cancer exosomes: Clinical implications, applications and challenges. Int. J. Cancer 2020, 146, 2946-2959. [CrossRef]

10. Mohammadi, S.; Yousefi, F.; Shabaninejad, Z.; Movahedpour, A.; Mahjoubin Tehran, M.; Shafiee, A.; Moradizarmehri, S.; Hajighadimi, S.; Savardashtaki, A.; Mirzaei, H. Exosomes and cancer: From oncogenic roles to therapeutic applications. IUBMB Life 2020, 72, 724-748. [CrossRef]

11. Parayath, N.N.; Padmakumar, S.; Amiji, M.M. Extracellular vesicle-mediated nucleic acid transfer and reprogramming in the tumor microenvironment. Cancer Lett. 2020, 482, 33-43. [CrossRef]

12. Wee, I.; Syn, N.; Sethi, G.; Goh, B.C.; Wang, L. Role of tumor-derived exosomes in cancer metastasis. Biochim. Biophys. Acta Rev. Cancer 2019, 1871, 12-19. [CrossRef]

13. Raimondo, S.; Pucci, M.; Alessandro, R.; Fontana, S. Extracellular vesicles and tumor-immune escape: Biological functions and clinical perspectives. Int. J. Mol. Sci. 2020, 21, 2286. [CrossRef]

14. Gilligan, K.E.; Dwyer, R.M. Extracellular Vesicles for Cancer Therapy: Impact of Host Immune Response. Cells 2020, 9, 224. [CrossRef] 
15. Li, X.; Corbett, A.L.; Taatizadeh, E.; Tasnim, N.; Little, J.P.; Garnis, C.; Daugaard, M.; Guns, E.; Hoorfar, M.; Li, I.T.S. Challenges and opportunities in exosome research-Perspectives from biology, engineering, and cancer therapy. APL Bioeng. 2019, 3, 011503. [CrossRef]

16. Srivastava, A.; Amreddy, N.; Pareek, V.; Chinnappan, M.; Ahmed, R.; Mehta, M.; Razaq, M.; Munshi, A.; Ramesh, R. Progress in extracellular vesicle biology and their application in cancer medicine. Wiley Interdiscip. Rev. Nanomed. Nanobiotechnol. 2020, 12, e1621. [CrossRef]

17. Taghikhani, A.; Farzaneh, F.; Sharifzad, F.; Mardpour, S.; Ebrahimi, M.; Hassan, Z.M. Engineered Tumor-Derived Extracellular Vesicles: Potentials in Cancer Immunotherapy. Front. Immunol. 2020, 11, 221. [CrossRef]

18. Stevic, I.; Buescher, G.; Ricklefs, F.L. Monitoring Therapy Efficiency in Cancer through Extracellular Vesicles. Cells 2020, 9, 130. [CrossRef]

19. Pullan, J.E.; Confeld, M.I.; Osborn, J.K.; Kim, J.; Sarkar, K.; Mallik, S. Exosomes as Drug Carriers for Cancer Therapy. Mol. Pharm. 2019, 16, 1789-1798. [CrossRef]

20. Yong, T.; Wang, D.; Li, X.; Yan, Y.; Hu, J.; Gan, L.; Yang, X. Extracellular vesicles for tumor targeting delivery based on five features principle. J. Control. Release 2020, 322, 555-565. [CrossRef]

21. Zhao, X.; Wu, D.; Ma, X.; Wang, J.; Hou, W.; Zhang, W. Exosomes as drug carriers for cancer therapy and challenges regarding exosome uptake. Biomed. Pharmacother. 2020, 128, 110237. [CrossRef]

22. Pirisinu, M.; Pham, T.C.; Zhang, D.X.; Hong, T.N.; Nguyen, L.T.; Le, M.T. Extracellular vesicles as natural therapeutic agents and innate drug delivery systems for cancer treatment: Recent advances, current obstacles, and challenges for clinical translation. Semin. Cancer Biol. 2020. [CrossRef]

23. Milane, L.; Singh, A.; Mattheolabakis, G.; Suresh, M.; Amiji, M.M. Exosome Mediated Communication within the Tumor Microenvironment. J. Control. Release 2015, 10, 278-294. [CrossRef]

24. Jenjaroenpun, P.; Kremenska, Y.; Nair, V.M.; Kremenskoy, M.; Joseph, B.; Kurochkin, I.V. Characterization of RNA in exosomes secreted by human breast cancer cell lines using next-generation sequencing. PeerJ 2013, 1, e201. [CrossRef]

25. Li, S.P.; Lin, Z.X.; Jiang, X.Y.; Yu, X.Y. Exosomal cargo-loading and synthetic exosome-mimics as potential therapeutic tools. Acta Pharmacol. Sin. 2018, 39, 542-551. [CrossRef]

26. Zhang, Y.; Liu, Y.; Liu, H.; Tang, W.H. Exosomes: Biogenesis, biologic function and clinical potential. Cell Biosci. 2019, 9, 19. [CrossRef]

27. Souza-Schorey, C.; Schorey, J.S. Regulation and mechanisms of extracellular vesicle biogenesis and secretion. Essays Biochem. 2018, 62, 125-133. [CrossRef]

28. Antonyak, M.A.; Cerione, R.A. Microvesicles as mediators of intercellular communication in cancer. Methods Mol. Biol. 2014, 1165, 147-173. [CrossRef]

29. Ghossoub, R.; Lembo, F.; Rubio, A.; Gaillard, C.B.; Bouchet, J.; Vitale, N.; Slavík, J.; Machala, M.; Zimmermann, P. Syntenin-ALIX exosome biogenesis and budding into multivesicular bodies are controlled by ARF6 and PLD2. Nat. Commun. 2014, 5, 3477. [CrossRef]

30. Kowal, J.; Tkach, M.; Théry, C. Biogenesis and secretion of exosomes. Curr. Opin. Cell Biol. 2014, 29, 116-125. [CrossRef]

31. Wortzel, I.; Dror, S.; Kenific, C.M.; Lyden, D. Exosome-Mediated Metastasis: Communication from a Distance. Dev. Cell 2019, 49, 347-360. [CrossRef]

32. Alenquer, M.; Amorim, M.J. Exosome biogenesis, regulation, and function in viral infection. Viruses 2015, 7, 5066-5083. [CrossRef]

33. Stoorvogel, W. Resolving sorting mechanisms into exosomes. Cell Res. 2015, 25, 531-532. [CrossRef]

34. Moloudizargari, M.; Asghari, M.H.; Abdollahi, M. Modifying exosome release in cancer therapy: How can it help? Pharmacol. Res. 2018, 134, 246-256. [CrossRef]

35. Lange, S.; Gallagher, M.; Kholia, S.; Kosgodage, U.S.; Hristova, M.; Hardy, J.; Inal, J.M. Peptidylarginine deiminases-Roles in cancer and neurodegeneration and possible avenues for therapeutic intervention via modulation of exosome and microvesicle (EMV) release? Int. J. Mol. Sci. 2017, 18, 1196. [CrossRef]

36. Mohrmann, K.; Leijendekker, R.; Gerez, L.; Van Sluijs, P. Der rab4 regulates transport to the apical plasma membrane in Madin-Darby canine kidney cells. J. Biol. Chem. 2002, 277, 10474-10481. [CrossRef]

37. Schlierf, B.; Fey, G.H.; Hauber, J.; Hocke, G.M.; Rosorius, O. Rab11b is essential for recycling of transferrin to the plasma membrane. Exp. Cell Res. 2000, 259, 257-265. [CrossRef]

38. Casanova, J.E.; Wang, X.; Kumar, R.; Bhartur, S.G.; Navarre, J.; Woodrum, J.E.; Altschuler, Y.; Ray, G.S.; Goldenring, J.R. Association of Rab25 and Rab11a with the apical recycling system of polarized Madin-Darby Canine Kidney cells. Mol. Biol. Cell 1999, 10, 47-61. [CrossRef]

39. Lombardi, D.; Soldati, T.; Riederer, M.A.; Goda, Y.; Zerial, M.; Pfeffer, S.R. Rab9 functions in transport between late endosomes and the trans Golgi network. EMBO J. 1993, 12, 677-682. [CrossRef]

40. Guerra, F.; Bucci, C. Multiple Roles of the Small GTPase Rab7. Cells 2016, 5, 34. [CrossRef]

41. Vitelli, R.; Santillo, M.; Lattero, D.; Chiariello, M.; Bifulco, M.; Bruni, C.B.; Bucci, C. Role of the small GTPase RAB7 in the late endocytic pathway. J. Biol. Chem. 1997, 272, 4391-4397. [CrossRef]

42. Chen, J.; Chopp, M. Exosome therapy for stroke. Stroke 2018, 49, 1083-1090. [CrossRef]

43. Ostrowski, M.; Carmo, N.B.; Krumeich, S.; Fanget, I.; Raposo, G.; Savina, A.; Moita, C.F.; Schauer, K.; Hume, A.N.; Freitas, R.P.; et al. Rab27a and Rab27b control different steps of the exosome secretion pathway. Nat. Cell Biol. 2010, 12, 19-30. [CrossRef]

44. Baietti, M.F.; Zhang, Z.; Mortier, E.; Melchior, A.; Degeest, G.; Geeraerts, A.; Ivarsson, Y.; Depoortere, F.; Coomans, C.; Vermeiren, E.; et al. Syndecan-syntenin-ALIX regulates the biogenesis of exosomes. Nat. Cell Biol. 2012, 14, 677-685. [CrossRef]

45. Savina, A.; Vidal, M.; Colombo, M.I. The exosome pathway in K562 cells is regulated by Rab11. J. Cell Sci. 2002, 115, 2505-2515. 
46. Savina, A.; Fader, C.M.; Damiani, M.T.; Colombo, M.I. Rab11 promotes docking and fusion of multivesicular bodies in a calcium-dependent manner. Traffic 2006, 6, 131-143. [CrossRef]

47. Li, W.; Hu, Y.; Jiang, T.; Han, Y.; Han, G.; Chen, J.; Li, X. Rab27A regulates exosome secretion from lung adenocarcinoma cells A549: Involvement of EPI64. APMIS 2014, 122, 1080-1087. [CrossRef]

48. Heusermann, W.; Hean, J.; Trojer, D.; Steib, E.; von Bueren, S.; Graff-Meyer, A.; Genoud, C.; Martin, K.; Pizzato, N.; Voshol, J.; et al. Exosomes surf on filopodia to enter cells at endocytic hot spots, traffic within endosomes, and are targeted to the ER. J. Cell Biol. 2016, 213, 173-184. [CrossRef]

49. Tian, T.; Zhu, Y.L.; Zhou, Y.Y.; Liang, G.F.; Wang, Y.Y.; Hu, F.H.; Xiao, Z.D. Exosome uptake through clathrin-mediated endocytosis and macropinocytosis and mediating miR-21 delivery. J. Biol. Chem. 2014, 289, 22258-22267. [CrossRef]

50. Nabi, I.R.; Le, P.U. Caveolae/raft-dependent endocytosis. J. Cell Biol. 2003, 161, 673-677. [CrossRef]

51. Gonda, A.; Kabagwira, J.; Senthil, G.N.; Wall, N.R. Internalization of exosomes through receptor-mediated endocytosis. Mol. Cancer Res. 2019, 17, 337-347. [CrossRef]

52. Joshi, B.S.; de Beer, M.A.; Giepmans, B.N.G.; Zuhorn, I.S. Endocytosis of Extracellular Vesicles and Release of Their Cargo from Endosomes. ACS Nano 2020, 14, 4444-4455. [CrossRef]

53. Andreu, Z.; Yáñez-Mó, M. Tetraspanins in extracellular vesicle formation and function. Front. Immunol. 2014, 5, 442. [CrossRef]

54. Wu, Y.; Wu, W.; Wong, W.M.; Ward, E.; Thrasher, A.J.; Goldblatt, D.; Osman, M.; Digard, P.; Canaday, D.H.; Gustafsson, K. Human $\gamma \delta$ T Cells: A Lymphoid Lineage Cell Capable of Professional Phagocytosis. J. Immunol. 2009, 183, 5622-5629. [CrossRef]

55. McKelvey, K.J.; Powell, K.L.; Ashton, A.W.; Morris, J.M.; McCracken, S.A. Exosomes: Mechanisms of Uptake. J. Circ. Biomark. 2015, 4, 7. [CrossRef]

56. Farooqi, A.A.; Desai, N.N.; Qureshi, M.Z.; Librelotto, D.R.N.; Gasparri, M.L.; Bishayee, A.; Nabavi, S.M.; Curti, V.; Daglia, M. Exosome biogenesis, bioactivities and functions as new delivery systems of natural compounds. Biotechnol. Adv. 2018, 36, 328-334. [CrossRef]

57. Datta, A.; Kim, H.; McGee, L.; Johnson, A.E.; Talwar, S.; Marugan, J.; Southall, N.; Hu, X.; Lal, M.; Mondal, D.; et al. HighThroughput screening identified selective inhibitors of exosome biogenesis and secretion: A drug repurposing strategy for advanced cancer. Sci. Rep. 2018, 8, 8161. [CrossRef]

58. Logozzi, M.; Spugnini, E.; Mizzoni, D.; Di Raimo, R.; Fais, S. Extracellular acidity and increased exosome release as key phenotypes of malignant tumors. Cancer Metastasis Rev. 2019, 38, 93-101. [CrossRef]

59. Agarwal, K.; Saji, M.; Lazaroff, S.M.; Palmer, A.F.; Ringel, M.D.; Paulaitis, M.E. Analysis of exosome release as a cellular response to MAPK pathway inhibition. Langmuir 2015, 31, 5440-5448. [CrossRef]

60. Lee, T.H.; Chennakrishnaiah, S.; Audemard, E.; Montermini, L.; Meehan, B.; Rak, J. Oncogenic ras-driven cancer cell vesiculation leads to emission of double-stranded DNA capable of interacting with target cells. Biochem. Biophys. Res. Commun. 2014, 451, 295-301. [CrossRef]

61. Al-Nedawi, K.; Meehan, B.; Micallef, J.; Lhotak, V.; May, L.; Guha, A.; Rak, J. Intercellular transfer of the oncogenic receptor EGFRvIII by microvesicles derived from tumour cells. Nat. Cell Biol. 2008, 10, 619-624. [CrossRef]

62. Zhang, C.; Xiao, X.; Chen, M.; Aldharee, H.; Chen, Y.; Long, W. Liver kinase B1 restoration promotes exosome secretion and motility of lung cancer cells. Oncol. Rep. 2018, 39, 376-382. [CrossRef]

63. Melo, S.A.; Sugimoto, H.; O'Connell, J.T.; Kato, N.; Villanueva, A.; Vidal, A.; Qiu, L.; Vitkin, E.; Perelman, L.T.; Melo, C.A.; et al. Cancer Exosomes Perform Cell-Independent MicroRNA Biogenesis and Promote Tumorigenesis. Cancer Cell 2014, 26, 707-721. [CrossRef]

64. Jia, Y.; Chen, Y.; Wang, Q.; Jayasinghe, U.; Luo, X.; Wei, Q.; Wang, J.; Xiong, H.; Chen, C.; Xu, B.; et al. Exosome: Emerging biomarker in breast cancer. Oncotarget 2017, 8, 41717-41733. [CrossRef]

65. Singh, R.; Pochampally, R.; Watabe, K.; Lu, Z.; Mo, Y.Y. Exosome-mediated transfer of miR-10b promotes cell invasion in breast cancer. Mol. Cancer 2014, 13, 256. [CrossRef]

66. Zhang, L.; Zhang, S.; Yao, J.; Lowery, F.J.; Zhang, Q.; Huang, W.C.; Li, P.; Li, M.; Wang, X.; Zhang, C.; et al. Microenvironmentinduced PTEN loss by exosomal microRNA primes brain metastasis outgrowth. Nature 2015, 527, 100-104. [CrossRef]

67. Cooks, T.; Pateras, I.S.; Jenkins, L.M.; Patel, K.M.; Robles, A.I.; Morris, J.; Forshew, T.; Appella, E.; Gorgoulis, V.G.; Harris, C.C. Mutant p53 cancers reprogram macrophages to tumor supporting macrophages via exosomal miR-1246. Nat. Commun. 2018, 9, 771. [CrossRef]

68. Zhang, H.D.; Jiang, L.H.; Hou, J.C.; Zhong, S.L.; Zhu, L.P.; Wang, D.D.; Zhou, S.Y.; Yang, S.J.; Wang, J.Y.; Zhang, Q.; et al. Exosome: A novel mediator in drug resistance of cancer cells. Epigenomics 2018, 10, 1499-1509. [CrossRef]

69. Yang, X.; Li, Y.; Zou, L.; Zhu, Z. Role of Exosomes in Crosstalk Between Cancer-Associated Fibroblasts and Cancer Cells. Front. Oncol. 2019, 9, 356. [CrossRef]

70. Zhao, H.; Yang, L.; Baddour, J.; Achreja, A.; Bernard, V.; Moss, T.; Marini, J.C.; Tudawe, T.; Seviour, E.G.; San Lucas, F.A.; et al. Tumor microenvironment derived exosomes pleiotropically modulate cancer cell metabolism. Elife 2016, 5, e10250. [CrossRef]

71. $\mathrm{Hu}, \mathrm{T}$; $\mathrm{Hu}$, J. Melanoma-derived exosomes induce reprogramming fibroblasts into cancer-associated fibroblasts via Gm26809 delivery. Cell Cycle 2019, 18, 3085-3094. [CrossRef]

72. Abusamra, A.J.; Zhong, Z.; Zheng, X.; Li, M.; Ichim, T.E.; Chin, J.L.; Min, W.P. Tumor exosomes expressing Fas ligand mediate CD8+ T-cell apoptosis. Blood Cells Mol. Dis. 2005, 35, 169-173. [CrossRef]

73. Lu, H.; Bowler, N.; Harshyne, L.A.; Craig Hooper, D.; Krishn, S.R.; Kurtoglu, S.; Fedele, C.; Liu, Q.; Tang, H.Y.; Kossenkov, A.V.; et al. Exosomal $\alpha \mathrm{v} \beta 6$ integrin is required for monocyte M2 polarization in prostate cancer. Matrix Biol. 2018, 70, 20-35. [CrossRef] 
74. Yin, C.; Han, Q.; Xu, D.; Zheng, B.; Zhao, X.; Zhang, J. SALL4-mediated upregulation of exosomal miR-146a-5p drives T-cell exhaustion by M2 tumor-associated macrophages in HCC. Oncoimmunology 2019, 8, 1601479. [CrossRef]

75. Liu, C.; Yu, S.; Zinn, K.; Wang, J.; Zhang, L.; Jia, Y.; Kappes, J.C.; Barnes, S.; Kimberly, R.P.; Grizzle, W.E.; et al. Murine Mammary Carcinoma Exosomes Promote Tumor Growth by Suppression of NK Cell Function. J. Immunol. 2006, 176, 1375-1385. [CrossRef]

76. Bobrie, A.; Krumeich, S.; Reyal, F.; Recchi, C.; Moita, L.F.; Seabra, M.C.; Ostrowski, M.; Théry, C. Rab27a supports exosomedependent and -independent mechanisms that modify the tumor microenvironment and can promote tumor progression. Cancer Res. 2012, 72, 4920-4930. [CrossRef]

77. Maus, R.L.G.; Jakub, J.W.; Nevala, W.K.; Christensen, T.A.; Noble-Orcutt, K.; Sachs, Z.; Hieken, T.J.; Markovic, S.N. Human melanoma-derived extracellular vesicles regulate dendritic cell maturation. Front. Immunol. 2017, 8, 358. [CrossRef]

78. Wolfers, J.; Lozier, A.; Raposo, G.; Regnault, A.; Théry, C.; Masurier, C.; Flament, C.; Pouzieux, S.; Faure, F.; Tursz, T.; et al. Tumorderived exosomes are a source of shared tumor rejection antigens for CTL cross-priming. Nat. Med. 2001, 7, 297-303. [CrossRef]

79. Theodoraki, M.N.; Yerneni, S.S.; Hoffmann, T.K.; Gooding, W.E.; Whiteside, T.L. Clinical significance of PD-L1 p exosomes in plasma of head and neck cancer patients. Clin. Cancer Res. 2018, 24, 896-905. [CrossRef]

80. Yue, S.; Mu, W.; Erb, U.; Zöller, M. The tetraspanins CD151 and Tspan8 are essential exosome components for the crosstalk between cancer initiating cells and their surrounding. Oncotarget 2015, 6, 2366-2384. [CrossRef]

81. Yin, X.; Zheng, X.; Liu, M.; Wang, D.; Sun, H.; Qiu, Y.; Chen, J.; Shi, B. Exosomal miR-663b targets Ets2-repressor factor to promote proliferation and the epithelial-mesenchymal transition of bladder cancer cells. Cell Biol. Int. 2020, 44, 958-965. [CrossRef]

82. Li, Z.; Jiang, P.; Li, J.; Peng, M.; Zhao, X.; Zhang, X.; Chen, K.; Zhang, Y.; Liu, H.; Gan, L.; et al. Tumor-derived exosomal lnc-Sox2ot promotes EMT and stemness by acting as a ceRNA in pancreatic ductal adenocarcinoma. Oncogene 2018, 37, 3822-3838. [CrossRef]

83. Suchorska, W.M.; Lach, M.S. The role of exosomes in tumor progression and metastasis (Review). Oncol. Rep. 2016, 35, 1237-1244. [CrossRef]

84. Fedele, C.; Singh, A.; Zerlanko, B.J.; Iozzo, R.V.; Languino, L.R. The $\alpha \mathrm{v} \beta 6$ integrin is transferred intercellularly via exosomes. J. Biol. Chem. 2015, 290, 4545-4551. [CrossRef]

85. Lin, F.; Yin, H.B.; Li, X.Y.; Zhu, G.M.; He, W.Y.; Gou, X. Bladder cancer cell-secreted exosomal miR-21 activates the PI3K/AKT pathway in macrophages to promote cancer progression. Int. J. Oncol. 2020, 56, 151-164. [CrossRef]

86. Zheng, P.; Luo, Q.; Wang, W.; Li, J.; Wang, T.; Wang, P.; Chen, L.; Zhang, P.; Chen, H.; Liu, Y.; et al. Tumor-associated macrophagesderived exosomes promote the migration of gastric cancer cells by transfer of functional Apolipoprotein E. Cell Death Dis. 2018, 9, 434. [CrossRef]

87. Zang, X.; Gu, J.; Zhang, J.; Shi, H.; Hou, S.; Xu, X.; Chen, Y.; Zhang, Y.; Mao, F.; Qian, H.; et al. Exosome-transmitted lncRNA UFC1 promotes non-small-cell lung cancer progression by EZH2-mediated epigenetic silencing of PTEN expression. Cell Death Dis. 2020, 11, 215. [CrossRef]

88. Pan, L.; Liang, W.; Fu, M.; Huang, Z.H.; Li, X.; Zhang, W.; Zhang, P.; Qian, H.; Jiang, P.C.; Xu, W.R.; et al. Exosomes-mediated transfer of long noncoding RNA ZFAS1 promotes gastric cancer progression. J. Cancer Res. Clin. Oncol. 2017, 143, 991-1004. [CrossRef]

89. Zhang, H.; Deng, T.; Liu, R.; Bai, M.; Zhou, L.; Wang, X.; Li, S.; Wang, X.; Yang, H.; Li, J.; et al. Exosome-delivered EGFR regulates liver microenvironment to promote gastric cancer liver metastasis. Nat. Commun. 2017, 8, 15016. [CrossRef]

90. Yokoi, A.; Yoshioka, Y.; Yamamoto, Y.; Ishikawa, M.; Ikeda, S.I.; Kato, T.; Kiyono, T.; Takeshita, F.; Kajiyama, H.; Kikkawa, F.; et al. Malignant extracellular vesicles carrying MMP1 mRNA facilitate peritoneal dissemination in ovarian cancer. Nat. Commun. 2017, 8, 14470. [CrossRef]

91. Wang, D.; Wang, X.; Si, M.; Yang, J.; Sun, S.; Wu, H.; Cui, S.; Qu, X.; Yu, X. Exosome-encapsulated miRNAs contribute to CXCL12/CXCR4-induced liver metastasis of colorectal cancer by enhancing M2 polarization of macrophages. Cancer Lett. 2020, 474, 36-52. [CrossRef]

92. Sun, S.; Chen, H.; Xu, C.; Zhang, Y.; Zhang, Q.; Chen, L.; Ding, Q.; Deng, Z. Exosomal miR-106b serves as a novel marker for lung cancer and promotes cancer metastasis via targeting PTEN. Life Sci. 2020, 244, 117297. [CrossRef]

93. Liao, J.; Liu, R.; Shi, Y.J.; Yin, L.H.; Pu, Y.P. Exosome-shuttling microRNA-21 promotes cell migration and invasion-targeting PDCD4 in esophageal cancer. Int. J. Oncol. 2016, 48, 2567-2579. [CrossRef]

94. Xia, Y.; Wei, K.; Hu, L.Q.; Zhou, C.R.; Lu, Z.B.; Zhan, G.S.; Pan, X.L.; Pan, C.F.; Wang, J.; Wen, W.; et al. Exosome-mediated transfer of miR-1260b promotes cell invasion through Wnt/ $\beta$-catenin signaling pathway in lung adenocarcinoma. J. Cell. Physiol. 2020, 235, 6843-6853. [CrossRef]

95. Li, Z.; Tao, Y.; Wang, X.; Jiang, P.; Li, J.; Peng, M.; Zhang, X.; Chen, K.; Liu, H.; Zhen, P.; et al. Tumor-secreted exosomal miR-222 promotes tumor progression via regulating P27 expression and re-localization in pancreatic cancer. Cell. Physiol. Biochem. 2018, 51, 610-629. [CrossRef]

96. Huang, Z.; Feng, Y. Exosomes derived from hypoxic colorectal cancer cells promote angiogenesis through Wnt4-Induced $\beta$-catenin signaling in endothelial cells. Oncol. Res. 2017, 25, 651-661. [CrossRef]

97. Treps, L.; Perret, R.; Edmond, S.; Ricard, D.; Gavard, J. Glioblastoma stem-like cells secrete the pro-angiogenic VEGF-A factor in extracellular vesicles. J. Extracell. Vesicles 2017, 6, 1359479. [CrossRef]

98. Yoshii, S.; Hayashi, Y.; Iijima, H.; Inoue, T.; Kimura, K.; Sakatani, A.; Nagai, K.; Fujinaga, T.; Hiyama, S.; Kodama, T.; et al. Exosomal microRNAs derived from colon cancer cells promote tumor progression by suppressing fibroblast TP53 expression. Cancer Sci. 2019, 110, 2396-2407. [CrossRef] 
99. Zheng, P.; Chen, L.; Yuan, X.; Luo, Q.; Liu, Y.; Xie, G.; Ma, Y.; Shen, L. Exosomal transfer of tumor-associated macrophage-derived miR-21 confers cisplatin resistance in gastric cancer cells. J. Exp. Clin. Cancer Res. 2017, 36, 53. [CrossRef]

100. Yu, X.; Zhang, Q.; Zhang, X.; Han, Q.; Li, H.; Mao, Y.; Wang, X.; Guo, H.; Irwin, D.M.; Niu, G.; et al. Exosomes from macrophages exposed to apoptotic breast cancer cells promote breast cancer proliferation and metastasis. J. Cancer 2019, 10, 2892-2906. [CrossRef]

101. Li, X.; Wang, S.; Zhu, R.; Li, H.; Han, Q.; Zhao, R.C. Lung tumor exosomes induce a pro-inflammatory phenotype in mesenchymal stem cells via NFKB-TLR signaling pathway. J. Hematol. Oncol. 2016, 9, 42. [CrossRef]

102. Raimondo, S.; Saieva, L.; Corrado, C.; Fontana, S.; Flugy, A.; Rizzo, A.; De Leo, G.; Alessandro, R. Chronic myeloid leukemiaderived exosomes promote tumor growth through an autocrine mechanism. Cell Commun. Signal. 2015, 13, 8. [CrossRef]

103. Wei, Y.; Lai, X.; Yu, S.; Chen, S.; Ma, Y.; Zhang, Y.; Li, H.; Zhu, X.; Yao, L.; Zhang, J. Exosomal miR-221/222 enhances tamoxifen resistance in recipient ER-positive breast cancer cells. Breast Cancer Res. Treat. 2014, 147, 423-431. [CrossRef]

104. Qin, X.; Yu, S.; Zhou, L.; Shi, M.; Hu, Y.; Xu, X.; Shen, B.; Liu, S.; Yan, D.; Feng, J. Cisplatin-resistant lung cancer cell-derived exosomes increase cisplatin resistance of recipient cells in exosomal miR-100-5p-dependent manner. Int. J. Nanomed. 2017, 12, 3721-3733. [CrossRef]

105. Richards, K.E.; Zeleniak, A.E.; Fishel, M.L.; Wu, J.; Littlepage, L.E.; Hill, R. Cancer-associated fibroblast exosomes regulate survival and proliferation of pancreatic cancer cells. Oncogene 2017, 36, 1770-1778. [CrossRef]

106. Han, M.; Gu, Y.; Lu, P.; Li, J.; Cao, H.; Li, X.; Qian, X.; Yu, C.; Yang, Y.; Yang, X.; et al. Exosome-mediated lncRNA AFAP1-AS1 promotes trastuzumab resistance through binding with AUF1 and activating ERBB2 translation. Mol. Cancer 2020, 19, 26. [CrossRef]

107. Xu, C.G.; Yang, M.F.; Ren, Y.Q.; Wu, C.H.; Wang, L.Q. Exosomes mediated transfer of lncRNA UCA1 results in increased tamoxifen resistance in breast cancer cells. Eur. Rev. Med. Pharmacol. Sci. 2016, 20, 4362-4368.

108. Wang, J.; Lv, B.; Su, Y.; Wang, X.; Bu, J.; Yao, L. Exosome-mediated transfer of lncRNA HOTTIP promotes cisplatin resistance in gastric cancer cells by regulating HMGA1/miR-218 axis. OncoTargets Ther. 2019, 12, 11325-11338. [CrossRef]

109. Weiner-Gorzel, K.; Dempsey, E.; Milewska, M.; Mcgoldrick, A.; Toh, V.; Walsh, A.; Lindsay, S.; Gubbins, L.; Cannon, A.; Sharpe, D.; et al. Overexpression of the microRNA miR-433 promotes resistance to paclitaxel through the induction of cellular senescence in ovarian cancer cells. Cancer Med. 2015, 4, 745-758. [CrossRef]

110. Xu, H.; Han, H.; Song, S.; Yi, N.; Qian, C.; Qiu, Y.; Zhou, W.; Hong, Y.; Zhuang, W.; Li, Z.; et al. Exosome-transmitted PSMA3 and PSMA3-AS1 promote proteasome inhibitor resistance in multiple myeloma. Clin. Cancer Res. 2019, 25, 1923-1935. [CrossRef]

111. Giallombardo, M.; Taverna, S.; Alessandro, R.; Hong, D.; Rolfo, C. Exosome-mediated drug resistance in cancer: The near future is here. Ther. Adv. Med. Oncol. 2016, 8, 320-322. [CrossRef] [PubMed]

112. Zhao, K.; Wang, Z.; Li, X.; Liu, J.L.; Tian, L.; Chen, J.Q. Exosome-mediated transfer of CLIC1 contributes to the vincristineresistance in gastric cancer. Mol. Cell. Biochem. 2019, 462, 97-105. [CrossRef] [PubMed]

113. Aung, T.; Chapuy, B.; Vogel, D.; Wenzel, D.; Oppermann, M.; Lahmann, M.; Weinhage, T.; Menck, K.; Hupfeld, T.; Koch, R.; et al. Exosomal evasion of humoral immunotherapy in aggressive B-cell lymphoma modulated by ATP-binding cassette transporter A3. Proc. Natl. Acad. Sci. USA 2011, 108, 15336-15341. [CrossRef] [PubMed]

114. Ciravolo, V.; Huber, V.; Ghedini, G.C.; Venturelli, E.; Bianchi, F.; Campiglio, M.; Morelli, D.; Villa, A.; Mina, P. Della Menard, S.; et al. Potential Role of Exosomes in Countering Trastuzumab-Based Therapy. J. Cell. Physiol. 2012, 227, 658-667. [CrossRef] [PubMed]

115. Harada, T.; Yamamoto, H.; Kishida, S.; Kishida, M.; Awada, C.; Takao, T.; Kikuchi, A. Wnt5b-associated exosomes promote cancer cell migration and proliferation. Cancer Sci. 2017, 108, 42-52. [CrossRef] [PubMed]

116. Pessolano, E.; Belvedere, R.; Bizzarro, V.; Franco, P.; De Marco, I.; Porta, A.; Tosco, A.; Parente, L.; Perretti, M.; Petrella, A. Annexin A1 may induce pancreatic cancer progression as a key player of extracellular vesicles effects as evidenced in the in vitro MIA PaCa-2 model system. Int. J. Mol. Sci. 2018, 19, 3878. [CrossRef] [PubMed]

117. Datta, A.; Kim, H.; Lal, M.; McGee, L.; Johnson, A.; Moustafa, A.A.; Jones, J.C.; Mondal, D.; Ferrer, M.; Abdel-Mageed, A.B Manumycin A suppresses exosome biogenesis and secretion via targeted inhibition of Ras/Raf/ERK1/2 signaling and hnRNP H1 in castration-resistant prostate cancer cells. Cancer Lett. 2017, 408, 73-81. [CrossRef] [PubMed]

118. Trajkovic, K.; Hsu, C.; Chiantia, S.; Rajendran, L.; Wenzel, D.; Wieland, F.; Schwille, P.; Brügger, B.; Simons, M. Ceramide triggers budding of exosome vesicles into multivesicular endosomes. Science 2008, 319, 1244-1247. [CrossRef]

119. Yang, Y.; Li, C.W.; Chan, L.C.; Wei, Y.; Hsu, J.M.; Xia, W.; Cha, J.H.; Hou, J.; Hsu, J.L.; Sun, L.; et al. Exosomal PD-L1 harbors active defense function to suppress $t$ cell killing of breast cancer cells and promote tumor growth. Cell Res. 2018, 28, 862-864. [CrossRef]

120. Kosaka, N.; Iguchi, H.; Hagiwara, K.; Yoshioka, Y.; Takeshita, F.; Ochiya, T. Neutral sphingomyelinase 2 (nSMase2)-dependent exosomal transfer of angiogenic micrornas regulate cancer cell metastasis. J. Biol. Chem. 2013, 288, 10849-10859. [CrossRef]

121. Roseblade, A.; Luk, F.; Ung, A.; Bebawy, M. Targeting Microparticle Biogenesis: A Novel Approach to the Circumvention of Cancer Multidrug Resistance. Curr. Cancer Drug Targets 2015, 15, 205-214. [CrossRef] [PubMed]

122. Peinado, H.; Alečković, M.; Lavotshkin, S.; Matei, I.; Costa-Silva, B.; Moreno-Bueno, G.; Hergueta-Redondo, M.; Williams, C.; García-Santos, G.; Ghajar, C.; et al. Melanoma exosomes educate bone marrow progenitor cells. Nat. Med. 2013, 18, 883-891. [CrossRef] [PubMed]

123. Guo, J.; Jayaprakash, P.; Dan, J.; Wise, P.; Jang, G.-B.; Liang, C.; Chen, M.; Woodley, D.T.; Fabbri, M.; Li, W. PRAS40 Connects Microenvironmental Stress Signaling to Exosome-Mediated Secretion. Mol. Cell. Biol. 2017, 37, e00171-17. [CrossRef] [PubMed]

124. Thyagarajan, A.; Kadam, S.M.; Liu, L.; Kelly, L.E.; Rapp, C.M.; Chen, Y.; Sahu, R.P. Gemcitabine induces microvesicle particle release in a platelet-activating factor-receptor-dependent manner via modulation of the MAPK pathway in pancreatic cancer cells. Int. J. Mol. Sci. 2019, 20, 32. [CrossRef] 
125. Kosgodage, U.S.; Trindade, R.P.; Thompson, P.R.; Inal, J.M. Chloramidine / Bisindolylmaleimide-I-Mediated Inhibition of Exosome and Microvesicle Release and Enhanced Efficacy of Cancer Chemotherapy. Int. J. Mol. Sci. 2017, 18, 1007. [CrossRef]

126. Featherby, S.; Madkhali, Y.; Maraveyas, A.; Ettelaie, C. Apixaban suppresses the release of TF-positive microvesicles and restrains cancer cell proliferation through directly inhibiting TF-fVIIa activity. Thromb. Haemost. 2019, 119, 1419-1432. [CrossRef]

127. Liu, J.; Zhang, Y.; Liu, A.; Wang, J.; Li, L.; Chen, X.; Gao, X. Distinct Dasatinib-Induced Mechanisms of Apoptotic Response and Exosome Release in Imatinib-Resistant Human Chronic Myeloid Leukemia Cells. Int. J. Mol. Sci. 2016, 17, 531. [CrossRef]

128. Huang, M.B.; Gonzalez, R.R.; Lillard, J.; Bond, V.C. Secretion modification region-derived peptide blocks exosome release and mediates cell cycle arrest in breast cancer cells. Oncotarget 2017, 8, 11302-11315. [CrossRef]

129. Plebanek, M.P.; Mutharasan, R.K.; Volpert, O.; Matov, A.; Gatlin, J.C.; Thaxton, C.S. Nanoparticle targeting and cholesterol flux through scavenger receptor type B-1 inhibits cellular exosome uptake. Sci. Rep. 2015, 5, 15724. [CrossRef]

130. Bastos, N.; Ruivo, C.F.; da Silva, S.; Melo, S.A. Exosomes in cancer: Use them or target them? Semin. Cell Dev. Biol. 2018, 78, 13-21. [CrossRef]

131. Zheng, Y.; Tu, C.; Zhang, J.; Wang, J. Inhibition of multiple myeloma-derived exosomes uptake suppresses the functional response in bone marrow stromal cell. Int. J. Oncol. 2019, 54, 1061-1070. [CrossRef] [PubMed]

132. Mrowczynski, O.D.; Madhankumar, A.B.; Sundstrom, J.M.; Zhao, Y.; Kawasawa, Y.I.; Slagle-Webb, B.; Mau, C.; Payne, R.A.; Rizk, E.B.; Zacharia, B.E.; et al. Exosomes impact survival to radiation exposure in cell line models of nervous system cancer. Oncotarget 2018, 9, 36083-36101. [CrossRef] [PubMed]

133. Sampey, G.C.; Meyering, S.S.; Asad Zadeh, M.; Saifuddin, M.; Hakami, R.M.; Kashanchi, F. Exosomes and their role in CNS viral infections. J. Neurovirol. 2014, 20, 199-208. [CrossRef] [PubMed]

134. Zhang, H.G.; Kim, H.; Liu, C.; Yu, S.; Wang, J.; Grizzle, W.E.; Kimberly, R.P.; Barnes, S. Curcumin reverses breast tumor exosomes mediated immune suppression of NK cell tumor cytotoxicity. Biochim. Biophys. Acta Mol. Cell Res. 2007, 1773, 1116-1123. [CrossRef] [PubMed]

135. Pucci, F.; Garris, C.; Lai, C.P.; Newton, A.; Pfirschke, C.; Engblom, C.; Alvarez, D.; Sprachman, M.; Evavold, C.; Magnuson, A.; et al. SCS macrophages suppress melanoma by restricting tumor-derived vesicle-B cell interactions. Science 2016, 352, 242-246. [CrossRef]

136. Evander, M.; Gidlöf, O.; Olde, B.; Erlinge, D.; Laurell, T. Non-contact acoustic capture of microparticles from small plasma volumes. Lab Chip 2015, 15, 2588-2596. [CrossRef]

137. Smyth, T.; Kullberg, M.; Malik, N.; Smith-Jones, P.; Graner, M.W.; Anchordoquy, T.J. Biodistribution and delivery efficiency of unmodified tumor-derived exosomes. J. Control. Release 2015, 199, 145-155. [CrossRef]

138. Nishida-Aoki, N.; Tominaga, N.; Takeshita, F.; Sonoda, H.; Yoshioka, Y.; Ochiya, T. Disruption of Circulating Extracellular Vesicles as a Novel Therapeutic Strategy against Cancer Metastasis. Mol. Ther. 2017, 25, 181-191. [CrossRef]

139. Bttpdjbufe, F.; Gspn, T.Q.; Chalmin, F.; Ladoire, S.; Mignot, G.; Vincent, J.; Bruchard, M.; Boireau, W.; Rouleau, A.; Simon, B.; et al. Membrane-associated Hsp72 from tumor-derived exosomes mediates STAT3-dependent immunosuppressive function of mouse and human myeloid-derived suppressor cells Fanny. J. Clin. Investig. 2010, 120, 457-471. [CrossRef]

140. Yoon, J.H.; Ashktorab, H.; Smoot, D.T.; Nam, S.W.; Hur, H.; Park, W.S. Uptake and tumor-suppressive pathways of exosomeassociated GKN1 protein in gastric epithelial cells. Gastric Cancer 2020, 23, 848-862. [CrossRef]

141. Zaharie, F.; Muresan, M.S.; Petrushev, B.; Berce, C.; Gafencu, G.A.; Selicean, S.; Jurj, A.; Cojocneanu-Petric, R.; Lisencu, C.I.; Pop, L.A.; et al. Exosome-carried microRNA-375 inhibits cell progression and dissemination via Bcl-2 blocking in colon cancer. J. Gastrointest. Liver Dis. 2015, 24, 435-443. [CrossRef] [PubMed]

142. Shi, H.; Li, H.; Zhen, T.; Dong, Y.; Pei, X.; Zhang, X. The Potential Therapeutic Role of Exosomal MicroRNA-520b Derived from Normal Fibroblasts in Pancreatic Cancer. Mol. Ther. Nucleic Acids 2020, 20, 373-384. [CrossRef] [PubMed]

143. Jeong, K.; Yu, Y.J.; You, J.Y.; Rhee, W.J.; Kim, J.A. Exosome-mediated microRNA-497 delivery for anti-cancer therapy in a microfluidic 3D lung cancer model. Lab Chip 2020, 20, 548-557. [CrossRef] [PubMed]

144. Chen, W.; Quan, Y.; Fan, S.; Wang, H.; Liang, J.; Huang, L.; Chen, L.; Liu, Q.; He, P.; Ye, Y. Exosome-transmitted circular RNA hsa_circ_0051443 suppresses hepatocellular carcinoma progression. Cancer Lett. 2020, 475, 119-128. [CrossRef]

145. Pakravan, K.; Babashah, S.; Sadeghizadeh, M.; Mowla, S.J.; Mossahebi-Mohammadi, M.; Ataei, F.; Dana, N.; Javan, M. MicroRNA100 shuttled by mesenchymal stem cell-derived exosomes suppresses in vitro angiogenesis through modulating the mTOR/HIF$1 \alpha /$ VEGF signaling axis in breast cancer cells. Cell. Oncol. 2017, 40, 457-470. [CrossRef]

146. Simpson, R.J.; Lim, J.W.E.; Moritz, R.L.; Mathivanan, S. Exosomes: Proteomic insights and diagnostic potential. Expert Rev. Proteomics 2009, 6, 267-283. [CrossRef]

147. Hornick, N.I.; Huan, J.; Doron, B.; Goloviznina, N.A.; Lapidus, J.; Chang, B.H.; Kurre, P. Serum Exosome MicroRNA as a minimally-invasive early biomarker of AML. Sci. Rep. 2015, 5, 11295. [CrossRef]

148. Sharma, R.; Huang, X.; Brekken, R.A.; Schroit, A.J. Detection of phosphatidylserine-positive exosomes for the diagnosis of early-stage malignancies. Br. J. Cancer 2017, 117, 545-552. [CrossRef]

149. Bu, H.; He, D.; He, X.; Wang, K. Exosomes: Isolation, Analysis, and Applications in Cancer Detection and Therapy. ChemBioChem 2019, 20, 451-461. [CrossRef]

150. Boukouris, S.; Mathivanan, S. Exosomes in bodily fluids are a highly stable resource of disease biomarkers. Proteomics Clin. Appl. 2015, 9, 358-367. [CrossRef] 
151. Munoz, J.L.; Bliss, S.A.; Greco, S.J.; Ramkissoon, S.H.; Ligon, K.L.; Rameshwar, P. Delivery of functional anti-miR-9 by mesenchymal stem cell-derived exosomes to glioblastoma multiforme cells conferred chemosensitivity. Mol. Ther. Nucleic Acids 2013, 2, e126. [CrossRef] [PubMed]

152. Syn, N.L.; Wang, L.; Chow, E.K.H.; Lim, C.T.; Goh, B.C. Exosomes in Cancer Nanomedicine and Immunotherapy: Prospects and Challenges. Trends Biotechnol. 2017, 35, 665-676. [CrossRef] [PubMed]

153. Viaud, S.; Terme, M.; Flament, C.; Taieb, J.; André, F.; Novault, S.; Escudier, B.; Robert, C.; Caillat-Zucman, S.; Tursz, T.; et al. Dendritic cell-derived exosomes promote natural killer cell activation and proliferation: A role for NKG2D ligands and IL-15R $\alpha$. PLoS ONE 2009, 4, e4942. [CrossRef] [PubMed]

154. Pitt, J.M.; André, F.; Amigorena, S.; Soria, J.C.; Eggermont, A.; Kroemer, G.; Zitvogel, L. Dendritic cell-derived exosomes for cancer therapy. J. Clin. Investig. 2016, 126, 1224-1232. [CrossRef]

155. Viaud, S.; Ploix, S.; Lapierre, V.; Théry, C.; Commere, P.H.; Tramalloni, D.; Gorrichon, K.; Virault-Rocroy, P.; Tursz, T.; Lantz, O.; et al. Updated technology to produce highly immunogenic dendritic cell-derived exosomes of clinical grade: A critical role of interferon- $\gamma$. J. Immunother. 2011, 34, 65-75. [CrossRef] [PubMed]

156. Vulpis, E.; Cecere, F.; Molfetta, R.; Soriani, A.; Fionda, C.; Peruzzi, G.; Caracciolo, G.; Palchetti, S.; Masuelli, L.; Simonelli, L.; et al. Genotoxic stress modulates the release of exosomes from multiple myeloma cells capable of activating NK cell cytokine production: Role of HSP70/TLR2/NF-kB axis. Oncoimmunology 2017, 6, e1279372. [CrossRef] [PubMed]

157. Xiao, W.; Dong, W.; Zhang, C.; Saren, G.; Geng, P.; Zhao, H.; Li, Q.; Zhu, J.; Li, G.; Zhang, S.; et al. Effects of the epigenetic drug MS-275 on the release and function of exosome-related immune molecules in hepatocellular carcinoma cells. Eur. J. Med. Res. 2013, 18, 61. [CrossRef] [PubMed]

158. Chen, W.; Wang, J.; Shao, C.; Liu, S.; Yu, Y.; Wang, Q.; Cao, X. Efficient induction of antitumor T cell immunity by exosomes derived from heat-shocked lymphoma cells. Eur. J. Immunol. 2006, 36, 1598-1607. [CrossRef] [PubMed]

159. Tan, A.; de la Peña, H.; Seifalian, A.M. The application of exosomes as a nanoscale cancer vaccine. Int. J. Nanomed. 2010, 5, 889-900.

160. Xie, Y.; Bai, O.; Zhang, H.; Yuan, J.; Zong, S.; Chibbar, R.; Slattery, K.; Qureshi, M.; Wei, Y.; Deng, Y.; et al. Membrane-bound HSP70-engineered myeloma cell-derived exosomes stimulate more efficient CD8+ CTL- and NK-mediated antitumour immunity than exosomes released from heat-shocked tumour cells expressing cytoplasmic HSP70. J. Cell. Mol. Med. 2010, 14, 2655-2666. [CrossRef]

161. Yang, Y.; Chen, Y.; Zhang, F.; Zhao, Q.; Zhong, H. Increased anti-tumour activity by exosomes derived from doxorubicin-treated tumour cells via heat stress. Int. J. Hyperth. 2015, 31, 498-506. [CrossRef] [PubMed]

162. Hao, S.; Bai, O.; Li, F.; Yuan, J.; Laferte, S.; Xiang, J. Mature dendritic cells pulsed with exosomes stimulate efficient cytotoxic T-lymphocyte responses and antitumour immunity. Immunology 2007, 120, 90-102. [CrossRef] [PubMed]

163. Yamashita, T.; Takahashi, Y.; Takakura, Y. Possibility of exosome-based therapeutics and challenges in production of exosomes eligible for therapeutic application. Biol. Pharm. Bull. 2018, 41, 835-842. [CrossRef] [PubMed]

164. Morishita, M.; Takahashi, Y.; Matsumoto, A.; Nishikawa, M.; Takakura, Y. Exosome-based tumor antigens-adjuvant co-delivery utilizing genetically engineered tumor cell-derived exosomes with immunostimulatory CpG DNA. Biomaterials 2016, 111, 55-65. [CrossRef] [PubMed]

165. Lu, Z.; Zuo, B.; Jing, R.; Gao, X.; Rao, Q.; Liu, Z.; Qi, H.; Guo, H.; Yin, H.F. Dendritic cell-derived exosomes elicit tumor regression in autochthonous hepatocellular carcinoma mouse models. J. Hepatol. 2017, 67, 739-748. [CrossRef]

166. Xiao, L.; Erb, U.; Zhao, K.; Hackert, T.; Zöller, M. Efficacy of vaccination with tumor-exosome loaded dendritic cells combined with cytotoxic drug treatment in pancreatic cancer. Oncoimmunology 2017, 6. [CrossRef]

167. Sedlik, C.; Vigneron, J.; Torrieri-Dramard, L.; Pitoiset, F.; Denizeau, J.; Chesneau, C.; de la Rochere, P.; Lantz, O.; Thery, C.; Bellier, B. Different immunogenicity but similar antitumor efficacy of two DNA vaccines coding for an antigen secreted in different membrane vesicle-associated forms. J. Extracell. Vesicles 2014, 3. [CrossRef]

168. Ohno, S.I.; Takanashi, M.; Sudo, K.; Ueda, S.; Ishikawa, A.; Matsuyama, N.; Fujita, K.; Mizutani, T.; Ohgi, T.; Ochiya, T.; et al. Systemically injected exosomes targeted to EGFR deliver antitumor microrna to breast cancer cells. Mol. Ther. 2013, 21, 185-191. [CrossRef]

169. Lang, F.M.; Hossain, A.; Gumin, J.; Momin, E.N.; Shimizu, Y.; Ledbetter, D.; Shahar, T.; Yamashita, S.; Parker Kerrigan, B.; Fueyo, J.; et al. Mesenchymal stem cells as natural biofactories for exosomes carrying miR-124a in the treatment of gliomas. Neuro-Oncology 2018, 20, 380-390. [CrossRef]

170. Zheng, R.; Du, M.; Wang, X.; Xu, W.; Liang, J.; Wang, W.; Lv, Q.; Qin, C.; Chu, H.; Wang, M.; et al. Exosome-transmitted long non-coding RNA PTENP1 suppresses bladder cancer progression. Mol. Cancer 2018, 17, 143. [CrossRef]

171. Shtam, T.A.; Kovalev, R.A.; Varfolomeeva, E.Y.; Makarov, E.M.; Kil, Y.V.; Filatov, M.V. Exosomes are natural carriers of exogenous siRNA to human cells in vitro. Cell Commun. Signal. 2013, 11, 88. [CrossRef] [PubMed]

172. Bellavia, D.; Raimondo, S.; Calabrese, G.; Forte, S.; Cristaldi, M.; Patinella, A.; Memeo, L.; Manno, M.; Raccosta, S.; Diana, P.; et al Interleukin 3- receptor targeted exosomes inhibit in vitro and in vivo chronic myelogenous Leukemia cell growth. Theranostics 2017, 7, 1333-1345. [CrossRef] [PubMed]

173. Kamerkar, S.; LeBleu, V.; Sugimoto, H.; Yang, S.; Ruivo, C.; Melo, S.A.; Lee, J.; Kalluri, R. Exosomes Facilitate Therapeutic Targeting of Oncogenic Kras in Pancreatic Cancer. Nature 2017, 546, 498-503. [CrossRef] [PubMed]

174. Zhao, L.; Gu, C.; Gan, Y.; Shao, L.; Chen, H.; Zhu, H. Exosome-mediated siRNA delivery to suppress postoperative breast cancer metastasis. J. Control. Release 2020, 318, 1-15. [CrossRef] [PubMed] 
175. Kim, G.; Kim, M.; Lee, Y.; Byun, J.W.; Hwang, D.W.; Lee, M. Systemic delivery of microRNA-21 antisense oligonucleotides to the brain using T7-peptide decorated exosomes. J. Control. Release 2020, 317, 273-281. [CrossRef]

176. Fatima, F.; Nawaz, M. Stem cell-derived exosomes: Roles in stromal remodeling, tumor progression, and cancer immunotherapy. Chin. J. Cancer 2015, 34, 541-553. [CrossRef]

177. Mendt, M.; Rezvani, K.; Shpall, E. Mesenchymal stem cell-derived exosomes for clinical use. Bone Marrow Transplant. 2019, 54, 789-792. [CrossRef]

178. Liang, Y.; Zhang, D.; Li, L.; Xin, T.; Zhao, Y.; Ma, R.; Du, J. Exosomal microRNA-144 from bone marrow-derived mesenchymal stem cells inhibits the progression of non-small cell lung cancer by targeting CCNE1 and CCNE2. Stem Cell Res. Ther. 2020, 11, 87. [CrossRef]

179. Xie, C.; Du, L.Y.; Guo, F.; Li, X.; Cheng, B. Exosomes derived from microRNA-101-3p-overexpressing human bone marrow mesenchymal stem cells suppress oral cancer cell proliferation, invasion, and migration. Mol. Cell. Biochem. 2019, 458, 11-26. [CrossRef]

180. Greco, K.A.; Franzen, C.A.; Foreman, K.E.; Flanigan, R.C.; Kuo, P.C.; Gupta, G.N. PLK-1 Silencing in Bladder Cancer by siRNA Delivered with Exosomes. Urology 2016, 91, 241.e1-241.e7. [CrossRef]

181. Hu, Q.; Su, H.; Li, J.; Lyon, C.; Tang, W.; Wan, M.; Hu, T.Y. Clinical applications of exosome membrane proteins. Precis. Clin. Med. 2020, 3, 54-66. [CrossRef] [PubMed]

182. Saari, H.; Lázaro-Ibáñez, E.; Viitala, T.; Vuorimaa-Laukkanen, E.; Siljander, P.; Yliperttula, M. Microvesicle- and exosome-mediated drug delivery enhances the cytotoxicity of Paclitaxel in autologous prostate cancer cells. J. Control. Release 2015, 220, 727-737. [CrossRef] [PubMed]

183. Wang, L.; Xie, Y.; Ahmed, K.A.; Ahmed, S.; Sami, A.; Chibbar, R.; Xu, Q.; Kane, S.E.; Hao, S.; Mulligan, S.J.; et al. Exosomal pMHC-I complex targets T cell-based vaccine to directly stimulate CTL responses leading to antitumor immunity in transgenic FVBneuN and HLA-A2/HER2 mice and eradicating trastuzumab-resistant tumor in athymic nude mice. Breast Cancer Res. Treat. 2013, 140, 273-284. [CrossRef] [PubMed]

184. Kim, M.S.; Haney, M.J.; Zhao, Y.; Yuan, D.; Deygen, I.; Klyachko, N.L.; Kabanov, A.V.; Batrakova, E.V. Engineering macrophagederived exosomes for targeted paclitaxel delivery to pulmonary metastases: In vitro and in vivo evaluations. Nanomed. Nanotechnol. Biol. Med. 2018, 14, 195-204. [CrossRef] [PubMed]

185. Srivastava, A.; Amreddy, N.; Babu, A.; Panneerselvam, J.; Mehta, M.; Muralidharan, R.; Chen, A.; Zhao, Y.D.; Razaq, M.; Riedinger, N.; et al. Nanosomes carrying doxorubicin exhibit potent anticancer activity against human lung cancer cells. Sci. Rep. 2016, 6, 38541. [CrossRef]

186. Gong, C.; Tian, J.; Wang, Z.; Gao, Y.; Wu, X.; Ding, X.; Qiang, L.; Li, G.; Han, Z.; Yuan, Y.; et al. Functional exosome-mediated codelivery of doxorubicin and hydrophobically modified microRNA 159 for triple-negative breast cancer therapy. J. Nanobiotechnol. 2019, 17, 93. [CrossRef]

187. Kim, M.S.; Haney, M.J.; Zhao, Y.; Mahajan, V.; Deygen, I.; Klyachko, N.L.; Inskoe, E.; Piroyan, A.; Sokolsky, M.; Hingtgen, S.D.; et al. Development of Exosome-encapsulated Paclitaxel to Overcome MDR in Cancer cells. Nanomedicine 2017, 12, 655-664. [CrossRef]

188. Hadla, M.; Palazzolo, S.; Corona, G.; Caligiuri, I.; Canzonieri, V.; Toffoli, G.; Rizzolio, F. Exosomes increase the therapeutic index of doxorubicin in breast and ovarian cancer mouse models. Nanomedicine 2016, 11, 2431-2441. [CrossRef]

189. Tian, Y.; Li, S.; Song, J.; Ji, T.; Zhu, M.; Anderson, G.J.; Wei, J.; Nie, G. A doxorubicin delivery platform using engineered natural membrane vesicle exosomes for targeted tumor therapy. Biomaterials 2014, 35, 2383-2390. [CrossRef]

190. Li, Y.J.; Wu, J.Y.; Wang, J.M.; Hu, X.B.; Cai, J.X.; Xiang, D.X. Gemcitabine loaded autologous exosomes for effective and safe chemotherapy of pancreatic cancer. Acta Biomater. 2020, 101, 519-530. [CrossRef]

191. Osterman, C.J.D.; Lynch, J.C.; Leaf, P.; Gonda, A.; Bennit, H.R.F.; Griffiths, D.; Wall, N.R. Curcumin modulates pancreatic adenocarcinoma cell-derived exosomal function. PLoS ONE 2015, 10, e0132845. [CrossRef] [PubMed]

192. Munagala, R.; Aqil, F.; Jeyabalan, J.; Agrawal, A.K.; Mudd, A.M.; Kyakulaga, A.H.; Singh, I.P.; Vadhanam, M.V.; Gupta, R.C. Exosomal formulation of anthocyanidins against multiple cancer types. Cancer Lett. 2017, 393, 94-102. [CrossRef] [PubMed]

193. Donoso-Quezada, J.; Guajardo-Flores, D.; González-Valdez, J. Exosomes as nanocarriers for the delivery of bioactive compounds from black bean extract with antiproliferative activity in cancer cell lines. Mater. Today Proc. 2019, 13, 362-369. [CrossRef]

194. Aqil, F.; Jeyabalan, J.; Agrawal, A.K.; Kyakulaga, A.H.; Munagala, R.; Parker, L.; Gupta, R.C. Exosomal delivery of berry anthocyanidins for the management of ovarian cancer. Food Funct. 2017, 8, 4100-4107. [CrossRef]

195. Aqil, F.; Kausar, H.; Agrawal, A.K.; Jeyabalan, J.; Kyakulaga, A.H.; Munagala, R.; Gupta, R. Exosomal formulation enhances therapeutic response of celastrol against lung cancer. Exp. Mol. Pathol. 2016, 101, 12-21. [CrossRef]

196. Bhattacharya, S.; Pal, K.; Sharma, A.K.; Dutta, S.K.; Lau, J.S.; Yan, I.K.; Wang, E.; Elkhanany, A.; Alkharfy, K.M.; Sanyal, A.; et al. GAIP interacting protein C-Terminus regulates autophagy and exosome biogenesis of pancreatic cancer through metabolic pathways. PLoS ONE 2014, 9, e114409. [CrossRef]

197. Kirave, P.; Gondaliya, P.; Kulkarni, B.; Rawal, R.; Garg, R.; Jain, A.; Kalia, K. Exosome mediated miR-155 delivery confers cisplatin chemoresistance in oral cancer cells via epithelial-mesenchymal transition. Oncotarget 2020, 11, 1157-1171. [CrossRef]

198. Kim, S.M.; Yang, Y.; Oh, S.J.; Hong, Y.; Seo, M.; Jang, M. Cancer-derived exosomes as a delivery platform of CRISPR/Cas9 confer cancer cell tropism-dependent targeting. J. Control. Release 2017, 266, 8-16. [CrossRef]

199. Zhang, Q.; Zhang, H.; Ning, T.; Liu, D.; Deng, T.; Liu, R.; Bai, M.; Zhu, K.; Li, J.; Fan, Q.; et al. Exosome-Delivered c-Met siRNA Could Reverse Chemoresistance to Cisplatin in Gastric Cancer. Int. J. Nanomed. 2020, 15, 2323-2335. [CrossRef]

200. Liu, T.; Zhang, X.; Du, L.; Wang, Y.; Liu, X.; Tian, H.; Wang, L.; Li, P.; Zhao, Y.; Duan, W.; et al. Exosome-transmitted miR-128-3p increase chemosensitivity of oxaliplatin-resistant colorectal cancer. Mol. Cancer 2019, 18, 43. [CrossRef] 
201. Lou, G.; Song, X.; Yang, F.; Wu, S.; Wang, J.; Chen, Z.; Liu, Y. Exosomes derived from MIR-122-modified adipose tissue-derived MSCs increase chemosensitivity of hepatocellular carcinoma. J. Hematol. Oncol. 2015, 8, 122. [CrossRef] [PubMed]

202. Han, M.; Hu, J.; Lu, P.; Cao, H.; Yu, C.; Li, X.; Qian, X.; Yang, X.; Yang, Y.; Han, N.; et al. Exosome-transmitted miR-567 reverses trastuzumab resistance by inhibiting ATG5 in breast cancer. Cell Death Dis. 2020, 11, 43. [CrossRef] [PubMed]

203. Cui, J.; Wang, H.; Zhang, X.; Sun, X.; Zhang, J.; Ma, J. Exosomal miR-200c suppresses chemoresistance of docetaxel in tongue squamous cell carcinoma by suppressing TUBB3 and PPP2R1B. Aging (Albany N. Y.) 2020, 12, 6756-6773. [CrossRef]

204. Lou, G.; Chen, L.; Xia, C.; Wang, W.; Qi, J.; Li, A.; Zhao, L.; Chen, Z.; Zheng, M.; Liu, Y. MiR-199a-modified exosomes from adipose tissue-derived mesenchymal stem cells improve hepatocellular carcinoma chemosensitivity through mTOR pathway. J. Exp. Clin. Cancer Res. 2020, 39, 4. [CrossRef] [PubMed]

205. Besse, B.; Charrier, M.; Lapierre, V.; Dansin, E.; Lantz, O.; Planchard, D.; Le Chevalier, T.; Livartoski, A.; Barlesi, F.; Laplanche, A.; et al. Dendritic cell-derived exosomes as maintenance immunotherapy after first line chemotherapy in NSCLC. Oncoimmunology 2016, 5, 1071008. [CrossRef] [PubMed]

206. Beit-Yannai, E.; Tabak, S.; Stamer, W.D. Physical exosome:exosome interactions. J. Cell. Mol. Med. 2018, 22, 2001-2006. [CrossRef] [PubMed]

207. Lunavat, T.R.; Jang, S.C.; Nilsson, L.; Park, H.T.; Repiska, G.; Lässer, C.; Nilsson, J.A.; Gho, Y.S.; Lötvall, J. RNAi delivery by exosome-mimetic nanovesicles-Implications for targeting c-Myc in cancer. Biomaterials 2016, 102, 231-238. [CrossRef]

208. Sato, Y.T.; Umezaki, K.; Sawada, S.; Mukai, S.A.; Sasaki, Y.; Harada, N.; Shiku, H.; Akiyoshi, K. Engineering hybrid exosomes by membrane fusion with liposomes. Sci. Rep. 2016, 6, 21933. [CrossRef] 